\title{
Review \\ Fate of Bioactive Compounds during Lactic Acid Fermentation of Fruits and Vegetables
}

\author{
Spiros Paramithiotis ${ }^{1, *,+}\left(\mathbb{D}\right.$, Gitishree Das ${ }^{2, \dagger}$, Han-Seung Shin ${ }^{3}$ and Jayanta Kumar Patra ${ }^{2, *}$ (i) \\ 1 Department of Food Science and Human Nutrition, Agricultural University of Athens, 11855 Athens, Greece \\ 2 Research Institute of Integrative Life Sciences, Dongguk University, Goyangsi 10326, Korea; \\ gdas@dongguk.edu \\ 3 Department of Food Science \& Biotechnology, Dongguk University, Goyangsi 10326, Korea; \\ spartan@dongguk.edu \\ * Correspondence: sdp@aua.gr (S.P.); jkpatra@dongguk.edu (J.K.P.) \\ + These authors contributed equally to this work.
}

check for updates

Citation: Paramithiotis, S.; Das, G.; Shin, H.-S.; Patra, J.K. Fate of Bioactive Compounds during Lactic Acid Fermentation of Fruits and Vegetables. Foods 2022, 11, 733. https://doi.org/10.3390/ foods 11050733

Academic Editor: Che Ok Jeon

Received: 4 February 2022

Accepted: 28 February 2022

Published: 2 March 2022

Publisher's Note: MDPI stays neutral with regard to jurisdictional claims in published maps and institutional affiliations.

Copyright: (C) 2022 by the authors. Licensee MDPI, Basel, Switzerland. This article is an open access article distributed under the terms and conditions of the Creative Commons Attribution (CC BY) license (https:// creativecommons.org/licenses/by/ $4.0 /)$.

\begin{abstract}
Consumption of lactic acid fermented fruits and vegetables has been correlated with a series of health benefits. Some of them have been attributed to the probiotic potential of lactic acid microbiota, while others to its metabolic potential and the production of bioactive compounds. The factors that affect the latter have been in the epicenter of intensive research over the last decade. The production of bioactive peptides, vitamins (especially of the B-complex), gamma-aminobutyric acid, as well as phenolic and organosulfur compounds during lactic acid fermentation of fruits and vegetables has attracted specific attention. On the other hand, the production of biogenic amines has also been intensively studied due to the adverse health effects caused by their consumption. The data that are currently available indicate that the production of these compounds is a strain-dependent characteristic that may also be affected by the raw materials used as well as the fermentation conditions. The aim of the present review paper is to collect all data referring to the production of the aforementioned compounds and to present and discuss them in a concise and comprehensive way.
\end{abstract}

Keywords: vitamins; GABA; phenolic compounds; organosulfur compounds; bioactive peptides; biogenic amines

\section{Introduction}

Lactic acid fermentation has been applied for centuries on substrates of plant and animal origin. The seasonal and geographical diversity of the raw materials results in a great variability of products. The qualitative and quantitative composition of the micro ecosystem that is developed during fermentation; the biotic and abiotic factors that direct it, along with the physicochemical changes of the substrate itself, have been in the epicenter of intensive research for many decades. Nowadays, the interest in lactic acid fermentation has been re-fueled, and its value has again been praised due to the health benefits that their consumption may confer. Indeed, a series of health benefits, including anti-allergic, antihypertensive, anti-inflammatory, anti-diarrheal, anti-infection, and anti-aging, as well as prevention and control of chronic diseases such as cardiovascular diseases, type 2 diabetes, obesity, and cancer, has been associated with the consumption of lactic acid fermented commodities. These health benefits have been attributed to the lactic acid bacteria that drive the fermentation as well as to the bioactive compounds that are present in the final product [1-8]. Their presence depends upon the occurrence of the necessary precursor molecules in the raw materials and the capacity of the lactic acid bacteria strains to carry out the required biotransformations.

Lactic acid fermentation of fruits and vegetables is no exception. Indeed, the suitability of fermented fruits and vegetables as probiotic carriers has been adequately exhibited [9-13] 
In addition, specific health benefits have been associated with the consumption of specific products, such as the antioxidant, anti-obesity, anti-cancer, anti-hypertensive, and immunomodulatory potential of kimchi [14].

The biotic and abiotic factors that affect the production of vitamins (especially of the B-complex), gamma-aminobutyric acid, bioactive peptides, as well as phenolic and organosulfur compounds during lactic acid fermentation of fruits and vegetables have attracted specific attention over the last decade. In addition, the production of biogenic amines has also been intensively studied due to the adverse health effects that are caused by their consumption. The aim of the present review paper is to collect all relevant information and to present and discuss them in a concise and comprehensive way.

\section{Vitamins}

The role of vitamins in human life and well-being is very important; they facilitate metabolic reactions, including energy-yielding ones, as well as many physiological processes. Depending on their chemical nature, they may be distinguished into water-soluble (B-complex, C) and fat-soluble (A, D, E, K) vitamins. They are considered essential micronutrients since the human body is not able to synthesize the majority of them. Thus, adequate dietary supply is necessary to prevent deficiency. Biofortification, i.e., the utilization of microorganisms capable of producing them, has been proposed as a strategy to improve the vitamin content of certain commodities. This approach is particularly valuable in the case of fermented fruits and vegetables.

The vitamin content of fruits and vegetables has been extensively studied. Fruits are recommended as sources of vitamin $\mathrm{C}$; they also contain vitamin $\mathrm{K}$ and carotenoids, and leafy vegetables contain vitamin $C$, folate, and carotenoids [15]. More specifically, cucumbers and Chinese cabbage contain vitamins C, B1, B2, B11, B3, B6, A, E, and K, with Chinese cabbage appearing to contain more per $100 \mathrm{~g}$. Olives contain vitamins B1, B3, B6, $\mathrm{A}, \mathrm{E}$, and $\mathrm{K}$; black olives also contain vitamin $\mathrm{C}$, while green olives also contain vitamin B11. Green olives appear to contain quantitatively more vitamins than black olives, with the exception of vitamin $\mathrm{K}$, where they both contain $1.4 \mathrm{mg} / 100 \mathrm{~g}$. Vitamins B12 and D seem to be absent from cucumbers, Chinese cabbage, and olives (data from fdc.nal.usda.gov, accessed on 29 July 2021).

Vitamin production by lactic acid bacteria has been in the epicenter of intensive research over the last decade, particularly vitamins of the B-complex and, more specifically, vitamins B2 (riboflavin), B9 (folate), and B12 (cobalamin). Vitamin production seems to be a strain-dependent property. Strains of Enterococcus faecium, Lactococcus lactis subsp. lactis, Lactobacillus acidophilus, Lactiplantibacillus plantarum, Limosilactobacillus fermentum, Lacticaseibacillus rhamnosus, Lm. mucosae, and Leuconostoc mesenteroides have been reported as riboflavin producers [16-23]. Extracellular folate production has been reported for strains of Streptococcus thermophilus, Lb. amylovorus, Lp. plantarum, Latilactobacillus sakei, and Lc. lactis. [24-28], while cobalamin production has been verified for strains belonging to the lactic acid bacteria species E. faecium, E. faecalis, La. casei, Furfurilactobacillus rossiae, Lm. reuteri, Lp. plantarum, Loigolactobacillus coryniformis, Lm. Fermentum, and La. rhamnosus [29-35]. The capacity of lactic acid bacteria strains to produce vitamin B1 (thiamine), B3 (niacin), as well as K2 has also been reported [36-38].

Although fruits and vegetables and, especially, green vegetables have been recognized as the main sources of folates for humans [39] and certain fruits and vegetables and, especially, dark green vegetables are very good sources of riboflavin [40], the fate of vitamins during lactic acid fermentation has only been marginally studied. Jagerstad et al. [41] reported that folate production takes place during lactic acid fermentation, depending on the starter culture. More accurately, the starter culture, consisting of a mixture of Lp. plantarum, Lc. lactis/cremoris and Leuconostoc sp. strains, was able to produce up to $125 \mu \mathrm{g} / \mathrm{kg} 5-\mathrm{CH} 3-\mathrm{H} 4$ folate during fermentation of a mixture of beetroots, turnips, and onions and $110 \mu \mathrm{g} / \mathrm{kg}$ during fermentation of a mixture of roots consisting of carrots, turnips, parsnips, celeriacs, and onions. Thompson et al. [42] used four Lp. plantarum strains 
to ferment cauliflower, white beans, and their 50:50 mixture and reported a statistically significant increase in riboflavin and folate content. More accurately, after fermentation of the latter at $30{ }^{\circ} \mathrm{C}$ for $44 \mathrm{~h}$, riboflavin increased to $75.64-91.60 \mu \mathrm{g} / 100 \mathrm{~g}$ fresh weight from the $42.83 \mu \mathrm{g} / 100 \mathrm{~g}$ fresh weight of the unfermented control; folate increased to $48.74-58.82 \mu \mathrm{g} / 100 \mathrm{~g}$ fresh weight from the $36.84 \mu \mathrm{g} / 100 \mathrm{~g}$ fresh weight of the unfermented control. In addition, Lp. plantarum strain 299 was able to produce vitamin B12, increasing its concentration to $0.048 \mu \mathrm{g} / 100 \mathrm{~g}$ fresh weight from the $0.029 \mu \mathrm{g} / 100 \mathrm{~g}$ fresh weight of the unfermented control.

\section{Gamma-Aminobutyric Acid}

The occurrence of gamma-aminobutyric acid (GABA) in plants, microorganisms, and vertebrates has been adequately exhibited. In plants and humans, GABA is mostly associated with signaling functions. Indeed, its role in plant growth and stress response has been established [43-45]. In humans, it acts as the major inhibitory neurotransmitter in the central nervous system. The latter has played a decisive role in the ongoing trend of enriching food with this molecule; however, Hepsomali et al. [46] mentioned that although GABA oral intake resulted in various responses [47-49], it is still unknown whether brain GABA concentration is increased. On the other hand, it seems to have a different role in microorganisms; it has been associated with resistance to acidic conditions [50] as well as spore germination, at least in Neurospora crassa [51] and Bacillus megaterium [52]. In lactic acid bacteria, GABA production has been reported as a strain-dependent characteristic. It takes place mostly through L-glutamate decarboxylation since it also contributes to acid resistance through proton consumption [53]. L-glutamate supply may be exogenous through the glutamate/GABA antiporter or endogenous through the activity of glutamate synthase on $\alpha$-ketoglutaric acid. Then, GABA may be transported extracellularly through the aforementioned antiporter or degraded to succinic acid through GABA aminotransferase and succinate semialdehyde dehydrogenase (Figure 1) Among others, strains belonging to $E$. durans, La. paracasei, La. rhamnosus, Lp. plantarum, Lb. delbrueckii subsp. bulgaricus, Lc. lactis subsp. lactis, Le. buchneri, Leu. mesenteroides, Leu. pseudomesenteroides, Lv. brevis, S. salivarius subsp. thermophilus, and Weissella cibaria have been reported as GABA-producers [54-56].

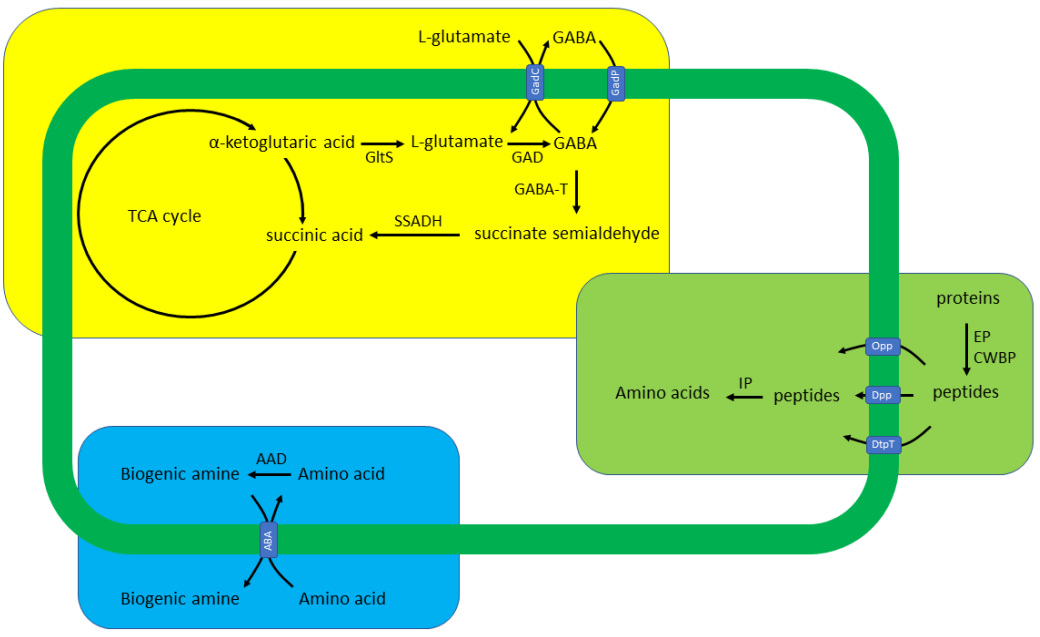

Figure 1. Production of GABA (yellow box), bioactive peptides (green box), and biogenic amines (blue box) by LAB. AAD: amino acid decarboxylase; ABA: amino acid/biogenic amine antiporter; CWBP: cell-wall-bound proteinases; Dpp: peptide (2-9 amino acids) ABC transporter; DtpT: ion linked peptide (2-3 amino acids) transporter; EP: extracellular proteinases; GABA-T: GABA aminotransferase; GAD: glutamate decarboxylase; GltS: glutamate synthase; IP: intracellular peptidases; Opp: oligopeptide (4-18 amino acids) permease; SSADH: succinate semialdehyde dehydrogenase.

The amount of GABA synthesized by a plant depends upon several factors, such as variety, type, and severity of biotic and abiotic stresses; however, its occurrence has been 
characterized as ubiquitous [57]. Indeed, GABA amount may range from the $0.007 \mathrm{mg} / \mathrm{g}$ dry weight in an epicarp/mesocarp mixture of apples and the $0.019 \mathrm{mg} / \mathrm{g}$ dry weight of chestnuts to the $1.86 \mathrm{mg} / \mathrm{g}$ dry weight of mulberries and the $174.30 \mathrm{mg} / \mathrm{g}$ fresh weight of Vitis vinifera L. cultivar Pinot Noir [58-61]. Regarding the raw materials mostly used as substrates for lactic acid fermentation, the occurrence of GABA has also been reported. In olives and in extra virgin olive oil, the amount of GABA was cultivar-dependent [62,63]. In the latter case, its amount was less than $0.00014 \mathrm{mg} / \mathrm{g}$. Leaves and roots of Chinese cabbage were reported to contain 4.69 and $7.02 \mu \mathrm{mol} / \mathrm{g}$ dry weight, respectively, accounting for the $8 \%$ and $26.86 \%$ of total free amino acids, respectively [64]. Finally, fresh cucumbers were reported to contain $105 \mathrm{mg} / \mathrm{kg}$ GABA [65]. Current evidence shows that lactic acid fermentation may increase GABA content. Indeed, spontaneously fermented cucumbers were reported to contain $150 \mathrm{mg} / \mathrm{kg}$ GABA, with the majority of it being formed during the first day of fermentation [65]. Notably, GABA concentration remained stable throughout the 6-month storage period at $28^{\circ} \mathrm{C}$. In the case of spontaneously fermented olives, GABA was formed only upon monosodium glutamate addition [66]. The amount of GABA formed was proportional to the amount of monosodium glutamate added and irrespective of the osmotic dehydration of olives, which was applied as a pre-fermentation treatment. GABA production was also reported during spontaneous kimchi fermentation [67]. In that study, GABA production took place within the first 25 days of storage at $4{ }^{\circ} \mathrm{C}$, reaching approximately $4 \mathrm{mM}$; this amount of GABA remained stable until the end of storage (120 days). Analysis of the microecosystem identified strains of Leuconostoc spp. and Lt. sakei as the GABA producers. Seok et al. [68], Cho et al. [69], and Lee et al. [70] studied GABA production during kimchi fermentation inoculated with GABA producing strains. Seok et al. [68] used Lactobacillus sp. strain OPK 2-59 and $5 \mathrm{~g}$ monosodium glutamate and managed to produce $18 \mathrm{mg} / 100 \mathrm{~g}$ GABA, a notable increase from the initial amount of $2.84-4.06 \mathrm{mg} / 100 \mathrm{~g}$. Interestingly, rapid GABA production was observed after the 9th day of storage. In the kimchi produced by the addition of either the GABA-producing strain or monosodium glutamate, the GABA amount at the end of storage ( $21 \mathrm{~d}$ ) was less than $6 \mathrm{mg} / 100 \mathrm{~g}$. Cho et al. [69] analyzed commercially available kimchi and Mukeunjee kimchi products and reported that the GABA content ranged from 1.9 to $12.9 \mathrm{mg} / 100 \mathrm{~g}$ and from 18.2 to $99.0 \mathrm{mg} / 100 \mathrm{~g}$, respectively. Then, a GABA-producing Le. buchneri strain was employed as a starter culture, resulting in kimchi with $61.7 \mathrm{mg} / 100 \mathrm{~g}$ GABA, which was significantly higher than the $8.1 \mathrm{mg} / 100 \mathrm{~g}$ of the spontaneously fermented one. Notably, the sensory scores of the products were comparable. Lee et al. [70] prepared kimchi with the addition of $L v$. zymae strain GU240 as a starter culture and evaluated the effect of L-glutamic acid, monosodium glutamate, and kelp extract as GABA precursors. Storage took place at $-1{ }^{\circ} \mathrm{C}$ for 20 weeks. Monosodium glutamate was the most effective GABA precursor. The most rapid increase was observed between weeks 2 and 4 , and the maximum GABA concentration reached $120.3 \mathrm{mg} / 100 \mathrm{~g}$ in week 8 . Then, it was reduced to the final amount of $95.6 \mathrm{mg} / 100 \mathrm{~g}$. The GABA content of the kimchi that was prepared without the addition of starter or precursor, as well as the kimchi prepared with only the addition of a starter, was $47 \mathrm{mg} / 100 \mathrm{~g}$. The addition of kelp extract resulted in the accumulation of $55 \mathrm{mg} / 100 \mathrm{~g} \mathrm{GABA}$, and the addition of L-glutamate resulted in $62.5 \mathrm{mg} / 100 \mathrm{~g}$. In all cases, maximum GABA concentration was observed in weeks 8 and 10, which was then reduced until the end of storage (week 20).

\section{Bioactive Peptides}

Bioactive peptides are short peptides that, upon release from the parent protein molecule, exert a biological function. Decryption from the parent protein molecule may take place during gastrointestinal digestion or due to the proteolytic activity of microorganisms, such as the LAB that direct a fermentation process. Their occurrence depends on the activity of extracellular and cell envelope proteinases, as well as the peptide transportation capacity into the cell, towards their complete hydrolysis to amino acids [71] (Figure 1). A wide range of biological activities has been described for such peptides, including anti- 
diabetic, antioxidant, anti-microbial, anti-thrombotic, hypocholesteromic, hypotensive, mineral-binding, opioid, and anti-opioid.

The liberation of bioactive peptides through lactic acid fermentation of protein-rich substrates, such as milk and soy, has been extensively studied. Data on the bioactivity of the peptides released by the lactic acid fermentation of meat, fish, grains, and legumes are also available. Thus, the decryption of such peptides through the application of LAB, such as E. faecalis, Lp. plantarum, Lb. helveticus, La. casei, La. rhamnosus, Companilactobacillus farciminis, Fructilactobacillus sanfranciscensis, Lc. lactis, Lb. delbrueckii subsp. lactis, and Pediococcus acidilactici single strains [35,72-81], or microbial consortia [82-90], has been reported.

In general, fruits and vegetables are not rich in protein; however, the occurrence of bioactive peptides in some of them has been reported (recently reviewed by Sosalagere et al. [91]). Cucumbers, Chinese cabbage, and green and black olives contain $0.65 \%, 1.5 \%, 1.03 \%$, and $0.84 \%$ protein, respectively (https:/ / fdc.nal.usda.gov/, accessed on 21 August 2021). In olive seeds, the occurrence of the peptide LLPSY exhibited significant anti-proliferative capacity on prostate cancer cells (PC-3) and breast cancer cells (MDA-MB-468) [92]. Occurrence of bioactive peptides in cucumbers that were raw, acidified, spontaneously fermented, or fermented with the addition of Lp. pentosus strain LA0445 was assessed by Fideler et al. [93]. Five peptides with potential anti-hypertensive activity were detected, namely, IPP, LPP, VPP, KP, and RY. KP was present in all cases; the amount in the fermented ones was significantly higher than the rest. Acidified cucumbers also contained KY, a peptide that was not detected in spontaneously fermented ones. The cucumbers that were fermented with the addition of the starter culture contained all five peptides [93].

\section{Phenolic Compounds}

The occurrence of phenolic compounds in plants has been extensively assessed. They are the third-largest group of secondary metabolites, after terpenes and alkaloids; they hold a very important physiological role as they participate in processes such as photosynthesis, respiration, and cell development. Regarding the total phenolic content (TPC) of the fruits and vegetables mostly used as a substrate of lactic acid fermentation, it seems to be rather low; it has been reported to vary between $0.58-1.42 \mathrm{mg} \mathrm{GAE} / \mathrm{g}$ fresh weight for Chinese cabbage, $0.17 \mathrm{mg}$ GAE/g fresh weight for cucumbers, and 82.29-287.29 mg $\mathrm{GAE} / 100 \mathrm{~g}$ for olives $[94,95]$. Their amount depends upon factors associated with the plant type and variety, cultivation conditions, processing, and storage [96,97]. The interest in phenolic compounds is fueled by the correlation that has been achieved between them and antioxidant capacity as well as the prevention of chronic diseases and inflammation [98].

Based on the fact that lactic-acid-fermented fruits and vegetables consist of two phases, namely, a solid and a liquid one, Ciniviz and Yildiz [99] studied the TPC of both juice and pulp portions of 30 kinds of lactic acid fermented fruits and vegetables. In all cases but two, namely, wild pears pickle and sour grapes pickle, the amount of TPC in juice was higher than the respective in the pulp portion. In the latter, TPC ranged from below detection limit in carrots pickle and white cabbage pickle to $135.39 \mu \mathrm{g} \mathrm{GAE} / \mathrm{mg}$ in pinecone pickle, while in the juice portion, it ranged from $16.94 \mu \mathrm{g}$ GAE/mg in tomatoes pickle to $235.19 \mu \mathrm{g} \mathrm{GAE} / \mathrm{mg}$ in pinecone pickle. The most common phenolic acid seemed to be sinapic acid, which was detected in all juice and pulp samples at concentrations ranging from $135.91 \mathrm{mg} / \mathrm{L}$ in sour grapes pickle to $236.32 \mathrm{mg} / \mathrm{L}$ in sweet long green pepper pickle and from $104.25 \mathrm{mg} / \mathrm{kg}$ in white cucumber pickle to $107.43 \mathrm{mg} / \mathrm{kg}$ in unripe melon pickle, respectively. Vanillic acid, caffeic acid, and chlorogenic acid were present in all juice samples, ranging from $0.08 \mathrm{mg} / \mathrm{L}$ in white cabbage pickle to $31.81 \mathrm{mg} / \mathrm{L}$ in carrot pickle, from $30.06 \mathrm{mg} / \mathrm{L}$ in unripe melon pickle and chard pickle to $74.61 \mathrm{mg} / \mathrm{L}$ in hot pepper pickle, and from $62.21 \mathrm{mg} / \mathrm{L}$ in cauliflower pickle to $200.30 \mathrm{mg} / \mathrm{L}$ in rock samphire pickle, respectively. 4-hydroxybenzoic acid and p-coumaric acid were not detected in any sample.

The fate of phenolic compounds during lactic acid fermentation has only been marginally studied. The mode by which lactic acid fermentation may increase the TPC of the raw materials is either through the lysis of the cell wall of the plant cells with concomi- 
tant facilitation of their release from the vacuole, in which they are mainly localized, or by enzymatic conversion of their glycosides into their aglycone form [100]. The latter may take place through $\beta$-glycosidase activity, which several lactic acid bacteria strains have exhibited [101,102]. Indeed, several Lp. plantarum strains have been reported to hydrolyze oleuropein, which is the main phenolic glucoside of olives [103]. More accurately, an initial action of $\beta$-glycosidase, followed by an esterolytic activity on the aglycone moiety, has been reported to produce olenoic acid and hydroxytyrosol [100]. Moreover, through the production of phenolic acid decarboxylases, some Lp. plantarum strains may decarboxylate phenolic acids $[104,105]$.

A wide range of phenolic compounds have been reported to occur in the brine or the flesh of fermented olives, including apigenin, apigenin-7-O-glucoside, caffeic acid, $\mathrm{p}$ coumaric acid, cyanidin-3-O-glucoside, cyanidin-3-O-rutinoside, ferulic acid, $\mathrm{p}$ hydroxybenzoic acid, hydroxytyrosol, luteolin, luteolin-4-O-glucoside, luteolin-7-O-glucoside, protocatechuic acid, pyrocathecol, rutin, tyrosol, vanillic acid, vanillin, and verbascoside [106-110]. Their fate during fermentation depends upon the cultivar, the addition and type of starter culture, brine composition, as well as fermentation temperature and time [107-109]. Indeed, proper arrangement of the aforementioned conditions may result in the complete decomposition of oleuropein and an increase in hydroxytyrosol, tyrosol, p-coumaric acid, vanillic acid, caffeic acid, verbascoside, and ferulic acid [107,109,110]. Initial concentration increase has also been reported for apigenin-7-O-glucoside, luteolin-4O-glucoside, and luteolin-7-O-glucoside, which was followed by a decrease until the end of fermentation [110].

In the case of kimchi, Park et al. [111] reported that over-ripened kimchi contained more TPC than short-term fermented ones. Park et al. [112] reported that the TPC of mustard kimchi increased during the first two months to $482.4 \mathrm{mg}$ GAE/g extract powder but then decreased during the third month to $475.3 \mathrm{mg}$ GAE/g extract powder, which had no statistically significant difference from the control. Regarding the specific phenolic compounds assessed, the amount of caffeic acid increased throughout the three months of fermentation; the amount of naringin, catechin gallate, and epigallocatechin gallate initially increased, but after three months of fermentation, their amount was less than that of the control. The amount of chlorogenic acid and epicatechin gallate decreased throughout the three-month fermentation compared to the control; $\mathrm{p}$-coumaric acid and gallocatechin gallate were only detected after one month of fermentation, and catechin was only detected after one and two months of fermentation. Epicatechin and rutin were present in the control, and their amount increased after two months of fermentation. However, they were not detected after three months of fermentation. Finally, gallic acid and epigallocatechin were not detected to the control and throughout fermentation. Oh et al. [113] studied the TPC of Dolsan leaf mustard kimchi and reported that the TPC of leaves decreased during the first 21 days of fermentation but then increased to the initial amount of ca. $100 \mathrm{mg}$ GAE/100 g. On the contrary, the TPC of stems gradually increased from the initial ca. $40 \mathrm{mg}$ GAE/100 $\mathrm{g}$ to a final of ca. $110 \mathrm{mg}$ GAE/100 g. A novel insight was provided by Jung et al. [114]. In that study, the increase of TPC over the 24-day fermentation of kimchi made of young Chinese cabbage was reported. However, the initial TPC and the TPC at the end of fermentation were determined at 83.2 and $102.5 \mathrm{mg} \mathrm{GAE} / 100 \mathrm{~g}$, respectively, when the young Chinese cabbage was cultivated using nature-friendly composts. These amounts of TPC were higher than 63.2 and $98.2 \mathrm{mg} \mathrm{GAE} / 100 \mathrm{~g}$, respectively, when the young Chinese cabbage was cultivated using general composts and higher than 57.9 and $81.0 \mathrm{mg}$ GAE/100 g, respectively, when the young Chinese cabbage was cultivated using chemical fertilizers.

Ciska et al. [115] and Kapusta-Duch et al. [116] studied the TPC of sauerkraut. The first study reported that sauerkraut extract contained $8.25 \mathrm{mg} / \mathrm{g}$ TPC while white cabbage contained $5.72 \mathrm{mg} / \mathrm{g}$. In white cabbage, only esterified phenolic acids were detected, with sinapic acid being the most prevalent $(278 \mu \mathrm{g} / \mathrm{g})$. On the contrary, apart from esterified phenolic acids, their glycosides were also detected in the sauerkraut extract. As in the previous 
case, sinapic acid was the prevalent one, with $20 \mu \mathrm{g} / \mathrm{g}$ being quantified as esterified acid and $84 \mu \mathrm{g} / \mathrm{g}$ as its glycoside. Kapusta-Duch et al. [116] assessed the effect of package type, namely, low-density polyethylene and metalized polyethylene terephthalate with polyethylene bags, on the TPC content during four months of chilled storage of white sauerkraut. It was revealed that package type had no effect on the TPC levels as in both cases, the reduction was at ca. $12 \%$ and $20 \%$ after three and four months of storage, respectively.

The fate of phenolic compounds has also been assessed in less known regional lactic acid fermented fruit and vegetable products, such as African nightshade leaves and kiwi fruit. In the first case, the effect of fermentation that was carried out at $37^{\circ} \mathrm{C}$ for 3 days on the phenolic profile of the product was strain-dependent [117]. For example, fermentation with $\mathrm{Lp}$. plantarum strain 75 resulted in an increase of the amount of gallic acid, vanillic acid, 2,5 dihydroxybenzoic acid, p-coumaric acid, and ellagic acid, as well as the flavonoids assessed, namely, catechin, quercetin, and luteolin. On the contrary, fermentation with Leu. pseudomesenteroides strain 56 resulted in an increase of the amount of ellagic acid and quercetin and a decrease in gallic acid, caffeic acid, vanillic acid, 2,5 dihydroxybenzoic acid, $\mathrm{p}$-coumaric acid, ferulic acid, and catechin. The effect of fermentation at $37^{\circ} \mathrm{C}$ for $28 \mathrm{~h}$ by Lp. plantarum on the phenolic profile of kiwifruit pulp was studied by Zhou et al. [118]. The TPC increased after the 21st hour of fermentation. The amount of protocatechuic acid, esculetin, and p-coumaric acid was increased due to the fermentation, while the amount of gallic acid, chlorogenic acid, catechin, and epicatechin was decreased.

\section{Organosulfur Compounds}

Vegetables of the family Brassicaceae are very rich in organosulfur compounds in general and glucosinolates in particular. Among others, this family includes all types of cabbage and mustard greens, which are very important raw materials for lactic acid fermentation.

Glucosinolates are secondary metabolites, the stability of which depend upon their contact with myrosinase, a $\beta$-thioglucosidase that catalyzes its decomposition. In intact plant cells, they are spatially separated; however, upon conditions that compromise plant tissue integrity, such as infection by herbivores and phytopathogenic microorganisms, the substrate and the enzyme are mixed, leading initially to the formation of the unstable thiohydroximate-O-sulfonate and $\beta$-D-glucose. The fate of the former depends on the nature of the side chain present in the glucosinolates molecule as well as the environmental conditions. Especially regarding the latter, neutral $\mathrm{pH}$ favors the formation of isothiocyanates while acidic $\mathrm{pH}$ in the presence of ferrous ions and epithiospecifier protein favors the formation of nitriles [119-121]. The physiological role of glucosinolates and their breakdown products, especially isothiocyanates, against biotic stresses has been verified [122]. Their concentration depends upon plant species, variety, and tissue, as well as environmental conditions and agricultural practices [123]. Although this response may indicate a possible role in abiotic stresses as well, this has not been yet clarified [122].

The interest on glucosinolates and their breakdown products results from their biological activity; many of them have exhibited anti-bacterial, anti-fungal, and anti-proliferative activity against human cancer cells [124]. The biotransformations of glucosinolates during lactic acid fermentation of Brassica vegetables have been studied to some extent. In general, fermentation seems to facilitate glucosinolates decomposition and an increase of the concentration of the breakdown products, the type and concentration of which are related to the glucosinolate type and concentration in the raw material as well as the capacity of the microbial strains that drive the fermentation.

Glucosinolate decomposition during fermentation has been exhibited in the case of sauerkraut [125-128] and has been primarily attributed to the shredding of the cabbage that precedes fermentation and secondarily to hydrolysis by lactic acid bacteria $[129,130]$. Interestingly, the capacity of LAB to produce nitriles instead of reduced glucosinolates, which were produced by Enterobacteriaceae, was highlighted by Mullaney et al. [129].

Ciska and Pathak [131] reported that glucobrassicin and sinigrin were the most abundant glucosinolates in the shredded cabbage used for fermentation. Ascorbigen, indole-3- 
carbinol, and indole-3-acetonitrile were identified as degradation products of the former, while allyl isothiocyanate, allyl cyanide, and 1-cyano-2,3-epithiopropane were identified as degradation products of the latter.

Penas et al. [132] highlighted the importance of the starter culture, cabbage cultivar, and fermentation conditions on the volatile glucosinolate breakdown products. Iberin, iberin nitrile, allyl isothiocyanate, sulforaphane, and allyl cyanide were detected, with the latter being the most abundant, ranging from 65 to $75 \mu \mathrm{mol} / 100 \mathrm{~g} \mathrm{DM}$. Ascorbigen has been reported as the most abundant glucosinolate degradation product in sauerkraut [126,128,131,133]. Ciska and Pathak [131] reported that ascorbigen concentration could be as high as $14 \mu \mathrm{mol} / 100 \mathrm{~g}$. Palani et al. [126] quantified ascorbigen at the end of fermentation at $13 \mu \mathrm{mol} / 100 \mathrm{~g}$ FW. Indole-3-acetonitrile was also present at the end of fermentation at $4.52 \mu \mathrm{mol} / 100 \mathrm{~g}$ FW. The concentration of both compounds decreased during storage at $4{ }^{\circ} \mathrm{C}$. These results concur with the ones presented by Penas et al. [133] but only as far as the decrease of ascorbigen concentration is concerned; the concentration of indole-3-carbinol and indole-3-acetonitrile was stable throughout three-month storage at $4{ }^{\circ} \mathrm{C}$. Ascorbigen was also reported by Ciska et al. [128] as the main glucobrassicin breakdown product in sauerkraut, which, at the end of fermentation, reached $9.59 \mu \mathrm{mol} / 100 \mathrm{~g}$. The concentration of indole-3-acetonitrile and 3,3'-diindolylmethane also increased during fermentation to 0.036 and $0.0099 \mu \mathrm{mol} / 100 \mathrm{~g}$, respectively. After 17 weeks of storage at $5^{\circ} \mathrm{C}$, the concentration of ascorbigen decreased to $8.59 \mu \mathrm{mol} / 100 \mathrm{~g}$, but the respective of indole-3-acetonitrile and 3,3'-diindolylmethane increased to 0.057 and $0.0187 \mu \mathrm{mol} / 100 \mathrm{~g}$, respectively. Regarding the decomposition products of aliphatic and aryl glucosinolates, an increase in the concentrations of allyl isothiocyanate, but-3enyl isothiocyanate, 3-(methylthio) propyl isothiocyanate, 1-cyano-3-(methylthio) propane, 4-(methylthio) butyl isothiocyanate, 3-(methylsulfinyl) propyl isothiocyanate, 1-cyano-3(methylsulfinyl) propane, 4-(methylsulfinyl) butyl isothiocyanate, and 2-phenethyl isothiocyanate was reported at the end of fermentation. Isothiocyanates increased during the first days of fermentation, reaching their peak on the 4th day and then decreasing. Allyl isothiocyanate was the most abundant breakdown product, with $2.848 \mu \mathrm{mol} / 100 \mathrm{~g}$, followed by 3-(methylsulfinyl) propyl isothiocyanate, with $2.453 \mu \mathrm{mol} / 100 \mathrm{~g}$. The concentration of all compounds decreased after 17 weeks of storage at $5{ }^{\circ} \mathrm{C}$, with the exception of 1-cyano-3-(methylthio) propane, which increased [128].

The significance of starter cultures in the fate of glucosinolates during the fermentation of broccoli puree and juice was highlighted by Cai et al. [134], Ye et al. [135], and Xu et al. [136]. Ye et al. [135] studied the effect of lactic acid fermentation of autoclaved broccoli puree using five Lp. plantarum and $2 \mathrm{Leu}$. mesenteroides strains on the glucosinolate content. In general, a total of 10 glucosinolates have been detected in broccoli florets, namely, glucoalyssin, glucobrassicanapin, glucobrassicin, 4-hydroxy glucobrassicin, 4-methoxy glucobrassicin, glucoerucin, glucoiberin, glucoraphanin, neoglucobrassicin, and progoitrin [137-139]. A strain-dependent increase in the concentration of glucoraphanin, glucoiberin, and progoitrin to 29.0-236.5, 16.1-56.2, and 24.5-65.9 $\mu \mathrm{g} / \mathrm{g}$, respectively, from the initial trace levels, was reported. Notably, the maximum amounts were achieved by Lp. plantarum strain F1. Xu et al. [136] reported an increase of glucoraphanin, a decrease of gluconapin, glucoerucin, 4-hydroxy-glucobrassicin, and neoglucobrassicin, and no statistically significant change in glucobrassicin and 4-methoxy-glucobrassicin when juice made of broccoli florets was fermented with two P. pentosaceus strains at $37{ }^{\circ} \mathrm{C}$ for $36 \mathrm{~h}$, in a strain-dependent manner. Finally, Cai et al. [134] reported that the preheating of broccoli florets at $65{ }^{\circ} \mathrm{C}$ for $3 \mathrm{~min}$ increased the concentration of sulforaphane, a glucoraphanin decomposition product, from the initial 806 to $3536 \mu \mathrm{mol} / \mathrm{kg}$ DW. Fermentation by a mixture of Lp. plantarum and Leu. mesenteroides strains at $30^{\circ} \mathrm{C}$ for $15 \mathrm{~h}$ further enhanced sulforaphane concentration to $13,121.3 \mu \mathrm{mol} / \mathrm{kg}$ DW, most likely by facilitating the release and accessibility of glucoraphanin for decomposition.

Endogenous myrosinase inactivation and concomitant sinigrin retention after lactic acid fermentation of Indian mustard leaves at $22{ }^{\circ} \mathrm{C}$ for $7 \mathrm{~d}$ were assessed by Nugrahedi et al. [140]. 
Although oven heat treatment at $35{ }^{\circ} \mathrm{C}$ for $2.5 \mathrm{~h}$ and microwave treatment at $180 \mathrm{~W}$ for 4.5 min effectively reduced myrosinase activity, complete inactivation was achieved by microwave treatment at $900 \mathrm{~W}$ for $2 \mathrm{~min}$, leading to the production of sayur asin with the sinigrin concentration of $11.4 \mu \mathrm{mol} / 10 \mathrm{~g} \mathrm{~d}$.m. Mustard leaves are also the basic ingredient for the production of mustard leaf kimchi. Oh et al. [113] studied the fate of glucosinolates during the fermentation of mustard leaf kimchi at $0{ }^{\circ} \mathrm{C}$ for $35 \mathrm{~d}$. Sinigrin, gluconapin, glucobrassicin, and glucoraphanin were detected at day 0 in both mustard leaves and stems; gluconasturtiin was only detected in leaves, while glucoiberin was only detected in stems. Reduction of the total amount of glucosinolates was evident throughout fermentation in both leaves and stems, which is mainly assigned to the reduction of sinigrin concentration, which was the most abundant glucosinolate; it was quantified at 21.43 and $22.47 \mathrm{mg} / 100 \mathrm{~g}$ at day 0 and 12.5 and $10.4 \mathrm{mg} / 100 \mathrm{~g}$ at day 35 in leaves and stems, respectively.

\section{Biogenic Amines}

Biogenic amines are compounds formed through the amination and transamination of aldehydes and ketones or the decarboxylation of amino acids. Their physiological role is very important. In plants, the role of polyamines in cell division [141], root growth [142-145], and vegetative propagation [146,147], as well as flower and fruit development [148-154], has been exhibited. Moreover, their role in abiotic and biotic stress responses has also been claimed [155-168]. Similarly, the contribution of cadaverine and dopamine to signaling stress response as well as plant growth and development has been reported $[169,170]$. In addition, tyramine and tryptamine are produced as defensive substances against aggressors [171] and serve as precursors for the production of alkaloids [172] and melatonin [173], respectively.

Regarding microbial physiology, the role of biogenic amines in gene expression [174,175], protection against oxidative stress [176-179], biofilm formation [180,181], signaling [182,183], and virulence $[184,185]$ has been indicated. From a fermentation perspective, the most important role seems to be the response mechanism against acid stress. This mechanism involves a membrane antiport, which couples amino acid uptake with biogenic amine excretion, and intracellular amino acid decarboxylases, which decarboxylate the inserted amino acid with simultaneous proton consumption (Figure 1). Then, the amine is excreted, and ATP synthesis through proton motive force is directed $[186,187]$. Such mechanisms have been reported for histidine/histamine, lysine/cadaverine, ornithine/putrescine, and tyrosine/tyramine [186,188,189].

Based on the above, the occurrence of biogenic amines in plant tissues seems justified even without microbial infection and proliferation. Indeed, several studies have reported their presence in nonfermented fruits, vegetables, nuts, legumes, and cereals (reviewed by Sanchez-Perez et al. [190]). Putrescine seems to be commonly occurring and may be accompanied by tyramine, cadaverine, spermine, spermidine, and even histamine [190,191]. This is also the case for white cabbage, Chinese cabbage, and cucumbers, which are commonly used as raw materials for lactic acid fermentation [192-198]. On the other hand, the occurrence of biogenic amines has not been reported in the flesh of fresh olives at any ripeness stage [199].

In Table 1, the outcome of studies on the quantitative determination of biogenic amines in fermented fruits and vegetables is summarized. Kimchi seems to be the most studied product, most likely due to the variety of raw materials employed, which results in a large diversity of products [14]. Regarding the mean values that have been reported, the highest were $16.81 \mathrm{mg} / \mathrm{kg}$ for agmatine [200], $14.3 \mathrm{and} 49.8 \mathrm{mg} / 100 \mathrm{~g}$ for cadaverine and histamine, respectively [201], $4.4 \mathrm{mg} / \mathrm{kg}$ for phenylethylamine [202], $334.64 \mathrm{mg} / \mathrm{kg}$ for putrescine [203], $31.30 \mathrm{mg} / \mathrm{kg}$ for spermine [204], and 24.6, 32.3 and $78.0 \mathrm{mg} / \mathrm{kg}$ for spermidine, tryptamine and tyramine, respectively [205]. Regarding the highest amounts, agmatine was reported at $86.0 \mathrm{mg} / \mathrm{kg}$ [200], phenylethylamine and tyramine at 15.75 and $181 \mathrm{mg} / \mathrm{kg}$, respectively [204], putrescine at $982.32 \mathrm{mg} / \mathrm{kg}$ [203], while for cadaverine, histamine, spermidine, spermine, and tryptamine were reported at 155, 535, 8.8, 12.1, and $11.4 \mathrm{mg} / 100 \mathrm{~g}$, respectively [201]. 
Table 1. Occurrence of biogenic amines in fermented fruits and vegetables.

\begin{tabular}{|c|c|c|c|c|c|c|c|c|c|c|}
\hline Product. & $\mathbf{N}$ & AGM & CAD & HIS & PHE & PUT & SPD & SPM & TRP & TYR \\
\hline \multicolumn{11}{|l|}{ Kimchi types } \\
\hline Kkakdugi kimchi $^{1}$ & 5 & & $\begin{array}{l}27.28(54.44) \\
{[<0.1-124.60]}\end{array}$ & $\begin{array}{c}55.94(44.45) \\
{[18.75-127.78]}\end{array}$ & $\begin{array}{c}3.61(6.55) \\
{[<0.1-15.24]}\end{array}$ & $\begin{array}{l}334.64(427.97) \\
{[10.85-982.32]}\end{array}$ & $\begin{array}{c}9.40(6.68) \\
{[<0.1-16.76]}\end{array}$ & $\begin{array}{l}1.03(1.31) \\
{[<0.1-3.10]}\end{array}$ & $<0.1$ & $\begin{array}{l}25.42(29.59) \\
{[2.97-76.95]}\end{array}$ \\
\hline Chonggak kimchi ${ }^{1}$ & 5 & & $\begin{array}{c}64.08(65.51) \\
{[2.00-148.50]}\end{array}$ & $\begin{array}{c}58.73(46.02) \\
{[8.24-131.20]}\end{array}$ & $\begin{array}{c}0.78(1.23) \\
{[<0.1-2.80]}\end{array}$ & $\begin{array}{c}269.07(349.93) \\
{[3.89-853.70]}\end{array}$ & $\begin{array}{c}9.06(2.99) \\
{[6.10-14.00]}\end{array}$ & $\begin{array}{c}6.23(8.79) \\
{[<0.1-20.74]}\end{array}$ & $\begin{array}{c}9.02(9.86) \\
{[<0.1-23.70]}\end{array}$ & $\begin{array}{c}8.49(6.80) \\
{[0.79-18.70]}\end{array}$ \\
\hline Pa kimchi $^{2}$ & 13 & & $\begin{array}{c}44.07(42.85) \\
{[<0.1-123.29]}\end{array}$ & $\begin{array}{c}155.85(139.26) \\
{[8.67-386.03]}\end{array}$ & $\begin{array}{c}1.77(2.04) \\
{[<0.1-5.97]} \\
\end{array}$ & $\begin{array}{c}78.79(79.00) \\
{[<0.1-158.33]}\end{array}$ & $\begin{array}{c}9.91(4.89) \\
{[2.32-18.74]}\end{array}$ & $\begin{array}{c}21.75(8.94) \\
{[<0.1-33.84]}\end{array}$ & $\begin{array}{c}6.99(5.74) \\
{[<0.1-14.92]}\end{array}$ & $\begin{array}{c}66.88(74.91) \\
{[<0.1-181.10}\end{array}$ \\
\hline Gat kimchi $^{2}$ & 13 & & $\begin{array}{c}20.5(18.52) \\
{[2.12-48.60]}\end{array}$ & $\begin{array}{c}58.44(75.77) \\
{[3.30-232.10]}\end{array}$ & $\begin{array}{c}3.44(4.30) \\
{[<0.1-15.75]}\end{array}$ & $\begin{array}{c}134.96(220.53) \\
{[1.89-720.82]}\end{array}$ & $\begin{array}{c}20.31(6.35) \\
{[12.26-28.49]}\end{array}$ & $\begin{array}{l}31.30(22.35) \\
{[<0.1-58.57]}\end{array}$ & $\begin{array}{c}11.22(8.23) \\
{[<0.1-26.74]}\end{array}$ & $\begin{array}{l}76.15(65.91) \\
{[1.28-149.77]} \\
\end{array}$ \\
\hline 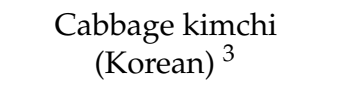 & 10 & & $\begin{array}{c}15.2 \\
{[3.6-44.9]}\end{array}$ & $\begin{array}{c}50.0 \\
{[3.4-142.3]}\end{array}$ & $\begin{array}{c}3.0 \\
{[n d-6.8]}\end{array}$ & $\begin{array}{c}69.7 \\
{[15.1-44.9]}\end{array}$ & $\begin{array}{c}12.0 \\
{[7.8-16.5]}\end{array}$ & $\begin{array}{c}2.4 \\
{[1.2-3.7]}\end{array}$ & $\begin{array}{c}12.3 \\
{[2.3-22.6]}\end{array}$ & $\begin{array}{c}49.4 \\
{[9.7-118.2]}\end{array}$ \\
\hline $\begin{array}{l}\text { Cabbage kimchi } \\
{\text { (Chinese })^{3}}^{\text {Che }}\end{array}$ & 10 & & $\begin{array}{c}12.5 \\
{[3.7-31.0]}\end{array}$ & $\begin{array}{c}2.7 \\
{[0.6-8.5]}\end{array}$ & $\begin{array}{c}4.4 \\
{[2.1-6.7]}\end{array}$ & $\begin{array}{c}70.6 \\
{[16.0-240.4]}\end{array}$ & $\begin{array}{c}11.9 \\
{[7.7-15.2]}\end{array}$ & $\begin{array}{c}2.1 \\
{[\mathrm{nd}-3.7]}\end{array}$ & $\begin{array}{c}12.1 \\
{[2.4-20.0]}\end{array}$ & $\begin{array}{c}35.1 \\
{[10.7-76.0]}\end{array}$ \\
\hline Baechu kimchi ${ }^{4}$ & 14 & & $\begin{array}{l}18.0(18.6) \\
\text { [nd-45.0] }\end{array}$ & & & $\begin{array}{c}64.6(73.1) \\
\text { [nd-245.9] }\end{array}$ & $\begin{array}{c}7.8(5.8) \\
{[n d-14.9]}\end{array}$ & & $\begin{array}{c}15.0(16.1) \\
{[\operatorname{tr}-43.9]}\end{array}$ & $\begin{array}{l}44.0(35.8) \\
{[\operatorname{tr}-103.6]}\end{array}$ \\
\hline Chonggak kimchi ${ }^{4}$ & 3 & & $\begin{array}{l}28.6(49.5) \\
\text { [nd-85.7] }\end{array}$ & & & $\begin{array}{l}10.7(10.2) \\
\text { [nd-20.3] }\end{array}$ & nd & & $\begin{array}{c}7.3(6.9) \\
{[2.3-15.2]}\end{array}$ & $\begin{array}{r}45.4(21.9) \\
{[20.2-58.1]}\end{array}$ \\
\hline Matkimchi $^{4}$ & 4 & & $\begin{array}{l}30.5(35.3) \\
{[\text { nd-64.2] }}\end{array}$ & & & $\begin{array}{c}72.1(27.7) \\
{[40.2-104.6]}\end{array}$ & $\begin{array}{c}5.2(4.5) \\
{[\text { nd-10.8] }}\end{array}$ & & $\begin{array}{l}32.3(26.9) \\
\text { [nd-60.5] }\end{array}$ & $\begin{array}{c}78.0(22.0) \\
{[54.3-105.1]}\end{array}$ \\
\hline $\begin{array}{l}\text { Ripened Baechu } \\
\text { kimchi }^{4}\end{array}$ & 4 & & $\begin{array}{l}55.7(18.9) \\
{[28.0-63.3]}\end{array}$ & & & $\begin{array}{c}110.3(44.4) \\
{[57.2-154.6]}\end{array}$ & $\begin{array}{c}24.6(34.0) \\
{[\operatorname{tr}-74.8]}\end{array}$ & & $\begin{array}{c}5.5(6.7) \\
\text { [nd-13.6] }\end{array}$ & $\begin{array}{l}46.6(39.6) \\
\text { [nd-95.6] }\end{array}$ \\
\hline Baek kimchi ${ }^{4}$ & 3 & & $\begin{array}{c}18.5(7.1) \\
{[11.5-25.6]}\end{array}$ & & & $\begin{array}{l}20.7(18.9) \\
{[1.9-39.6]}\end{array}$ & $\begin{array}{r}0.8(0.9) \\
{[\text { nd-1.7] }}\end{array}$ & & $\operatorname{tr}$ & $\begin{array}{l}36.4(28.6) \\
{[7.8-64.9]}\end{array}$ \\
\hline Super market kimchi ${ }^{5}$ & 20 & $<0.1$ & $\begin{array}{c}14.3(9.2) \\
{[<0.1-155]}\end{array}$ & $\begin{array}{l}49.8(32.5) \\
{[<0.1-535]}\end{array}$ & $<0.1$ & $\begin{array}{l}2.06(1.33) \\
{[<0.1-7.3]}\end{array}$ & $\begin{array}{l}0.65(0.51) \\
{[<0.1-8.8]}\end{array}$ & $\begin{array}{c}1.96(1.31) \\
{[<0.1-12.1]}\end{array}$ & $\begin{array}{c}1.0(1.05) \\
{[<0.1-11.4]}\end{array}$ & $\begin{array}{l}0.46(0.48) \\
{[<0.1-4.2]}\end{array}$ \\
\hline Retail market kimchi ${ }^{5}$ & 17 & $<0.1$ & $\begin{array}{l}1.59(1.44) \\
{[<0.1-4.8]}\end{array}$ & $\begin{array}{l}5.59(4.57) \\
{[<0.1-18.6]}\end{array}$ & $<0.1$ & $\begin{array}{l}0.67(0.79) \\
{[<0.1-5.1]}\end{array}$ & $\begin{array}{l}0.48(0.52) \\
{[<0.1-8.2]}\end{array}$ & $<0.1$ & $<0.1$ & $\begin{array}{l}0.40(0.65) \\
{[<0.1-3.5]}\end{array}$ \\
\hline
\end{tabular}


Table 1. Cont.

\begin{tabular}{|c|c|c|c|c|c|c|c|c|c|c|}
\hline Product. & $\mathbf{N}$ & AGM & CAD & HIS & PHE & PUT & SPD & SPM & TRP & TYR \\
\hline Cabbage kimchi ${ }^{6}$ & 20 & & $\begin{array}{c}8.3 \\
{[0.9-39.8]}\end{array}$ & $\begin{array}{c}6.3 \\
{[\mathrm{nd}-21.8]}\end{array}$ & $\begin{array}{c}0.5 \\
{[\mathrm{nd}-2.0]}\end{array}$ & $\begin{array}{c}47.6 \\
{[2.3-148.6]}\end{array}$ & $\begin{array}{c}2.9 \\
{[\mathrm{nd}-6.7]}\end{array}$ & $\begin{array}{c}1.1 \\
{[\mathrm{nd}-5.1]}\end{array}$ & $\begin{array}{c}11.6 \\
{[n d-74.8]}\end{array}$ & $\begin{array}{c}8.3 \\
{[1.1-27.9]}\end{array}$ \\
\hline Kimchi $^{7}$ & $\mathrm{ud}$ & $\begin{array}{c}16.81(30.81) \\
{[<0.14-86.00]}\end{array}$ & $\begin{array}{l}63.51(69.81) \\
{[1.13-193.00]}\end{array}$ & $\begin{array}{c}18.53(28.07) \\
{[<0.09-74.94]}\end{array}$ & $\begin{array}{r}2.59(1.27) \\
{[0.94-4.50]}\end{array}$ & $\begin{array}{c}208.70(186.90) \\
{[2.25-475.06]}\end{array}$ & $\begin{array}{c}10.35(4.49) \\
{[5.55-18.25]}\end{array}$ & $\begin{array}{c}1.38(0.68) \\
{[0.56-2.38]}\end{array}$ & $\begin{array}{c}4.75(9.41) \\
{[<0.29-24.88]}\end{array}$ & $\begin{array}{l}59.11(44.70) \\
{[1.25-98.31]}\end{array}$ \\
\hline \multicolumn{11}{|c|}{ Sauerkaut } \\
\hline Czech $^{8}$ & 53 & & $\begin{array}{l}64.8(56.8) \\
{[1.9-293]}\end{array}$ & $\begin{array}{l}12.1(31.6) \\
\text { [nd-229] }\end{array}$ & & $\begin{array}{l}181(108) \\
{[2.8-529]}\end{array}$ & $\begin{array}{c}8.2(7.3) \\
{[\text { nd-47.0] }}\end{array}$ & & $\begin{array}{c}4.6(9.0) \\
{[\text { nd-36.5] }}\end{array}$ & $\begin{array}{l}235(213) \\
\text { [nd-951] }\end{array}$ \\
\hline Austrian $^{8}$ & 10 & & $\begin{array}{l}43.4(21.0) \\
{[19.3-77.4]}\end{array}$ & $\begin{array}{l}2.1(2.4) \\
\text { [nd-8.0] }\end{array}$ & & $\begin{array}{c}179(80.2) \\
{[51.0-295]}\end{array}$ & $\begin{array}{c}6.5(5.5) \\
{[\text { [nd-16.9] }}\end{array}$ & & $\begin{array}{l}2.4(3.2) \\
{[\text { nd-7.7] }}\end{array}$ & $\begin{array}{r}130(71.3) \\
{[14.0-214]}\end{array}$ \\
\hline Household $^{8}$ & 29 & & $\begin{array}{l}29.8(23.0) \\
{[\text { nd-82.7] }}\end{array}$ & $\begin{array}{c}4.6(6.8) \\
{[\text { [nd-32.4] }}\end{array}$ & & $\begin{array}{l}87.3(72.2) \\
{[4.3-260]}\end{array}$ & $\begin{array}{l}10.2(7.5) \\
{[\text { [nd-28.3] }}\end{array}$ & & $\begin{array}{c}4.7(7.9) \\
{[\text { [nd-28.1] }}\end{array}$ & $\begin{array}{l}117(113) \\
\text { [nd-384] }\end{array}$ \\
\hline Sterilized $^{8}$ & 29 & & $\begin{array}{l}45.5(40.1) \\
{[6.9-167]}\end{array}$ & $\begin{array}{c}4.9(6.4) \\
{[\text { [nd-26.4] }}\end{array}$ & & $\begin{array}{c}132(81.5) \\
{[18.4-359]}\end{array}$ & $\begin{array}{l}6.8(4.0) \\
{[\text { [nd-15.2] }}\end{array}$ & & $\begin{array}{l}7.2(10.2) \\
{[\text { [nd-37.5] }}\end{array}$ & $\begin{array}{l}134(90.4) \\
{[26.3-345]}\end{array}$ \\
\hline Sauerkraut $^{9}$ & & & 3.9 & 1.5 & $\operatorname{tr}$ & 9.2 & 0.5 & 0.2 & nd & 4.8 \\
\hline \multicolumn{11}{|c|}{ Cucumbers } \\
\hline $\begin{array}{l}\text { Fermented cucumber } \\
\text { brine } 10\end{array}$ & 1 & 3.19 & 45.11 & 3.07 & 1.83 & 61.70 & 21.16 & 9.77 & 7.37 & 5.24 \\
\hline Pickled cucumbers ${ }^{11}$ & 11 & & nd & nd & & $4.5(5.0)$ & & $2.9(4.2)$ & & $0.7(0.8)$ \\
\hline Cucumber $^{7}$ & $\mathrm{ud}$ & $\begin{array}{c}0.65(1.05) \\
{[<0.14-2.88]}\end{array}$ & $\begin{array}{c}82.14(44.03) \\
{[39.60-179.19]}\end{array}$ & $\begin{array}{c}31.54(7.43) \\
{[18.50-40.85]}\end{array}$ & $\begin{array}{c}3.10(1.64) \\
{[1.15-6.31]}\end{array}$ & $\begin{array}{c}171.30(55.46) \\
{[103.13-} \\
286.88]\end{array}$ & $\begin{array}{c}8.08(3.77) \\
{[2.25-14.05]}\end{array}$ & $\begin{array}{c}1.28(0.71) \\
{[0.56-2.65]}\end{array}$ & $\begin{array}{c}14.49(5.82) \\
{[6.00-22.88]}\end{array}$ & $\begin{array}{l}62.24(20.12) \\
{[28.38-86.75}\end{array}$ \\
\hline \multicolumn{11}{|c|}{ Olives } \\
\hline $\begin{array}{l}\text { Fermented olive brine } \\
10\end{array}$ & 1 & 0.81 & 15.62 & 1.14 & 1.78 & 42.94 & & & 0.51 & 6.93 \\
\hline Olives $^{7}$ & $\mathrm{ud}$ & $<0.14$ & $\begin{array}{c}2.54(3.28) \\
{[<0.06-6.25]}\end{array}$ & $\begin{array}{c}1.71(1.58) \\
{[<0.09-3.13]}\end{array}$ & $\begin{array}{c}0.23(0.40) \\
{[<0.35-0.70]}\end{array}$ & $\begin{array}{l}17.13(15.00) \\
{[5.75-34.13]}\end{array}$ & $\begin{array}{c}1.21(0.85) \\
{[0.25-1.88]}\end{array}$ & $\begin{array}{c}1.58(0.85) \\
{[0.60-2.13]}\end{array}$ & $\begin{array}{c}3.33(5.77) \\
{[<0.29-10.00]}\end{array}$ & $\begin{array}{c}2.56(1.29) \\
{[1.75-4.05]}\end{array}$ \\
\hline Olives ${ }^{12}$ & 7 & & $\begin{array}{l}0.80(0.00) \\
{[<0.4-0.8]}\end{array}$ & nd & & $\begin{array}{l}5.00(2.96) \\
{[<0.5-7.8]}\end{array}$ & & & & nd \\
\hline
\end{tabular}


Table 1. Cont.

\begin{tabular}{|c|c|c|c|c|c|c|c|c|c|c|}
\hline Product. & $\mathbf{N}$ & AGM & CAD & HIS & PHE & PUT & SPD & SPM & TRP & TYR \\
\hline \multicolumn{11}{|c|}{ Various products } \\
\hline Beetroot $^{7}$ & ud & $\begin{array}{c}0.48(0.94) \\
{[<0.14-2.50]}\end{array}$ & $\begin{array}{c}5.45(7.96) \\
{[0.10-20.50]}\end{array}$ & $\begin{array}{c}6.84(12.84) \\
{[<0.09-31.25]}\end{array}$ & $\begin{array}{c}0.63(0.96) \\
{[<0.35-2.25]}\end{array}$ & $\begin{array}{l}21.25(33.98) \\
{[1.80-80.65]}\end{array}$ & $\begin{array}{c}2.31(0.54) \\
{[1.35-3.00]}\end{array}$ & $\begin{array}{c}0.80(0.84) \\
{[0.45-2.88]}\end{array}$ & $\begin{array}{c}2.46(5.08) \\
{[<0.29-14.20]}\end{array}$ & $\begin{array}{l}16.76(20.18) \\
{[1.20-47.80]}\end{array}$ \\
\hline Broccoli $^{7}$ & ud & $\begin{array}{c}0.93(1.85) \\
{[<0.14-3.70]}\end{array}$ & $\begin{array}{c}119.42(127.40) \\
{[6.80-302.50]}\end{array}$ & $\begin{array}{c}36.86(42.95) \\
{[<0.09-98.95]}\end{array}$ & $\begin{array}{c}2.40(0.56) \\
{[1.88-3.06]}\end{array}$ & $\begin{array}{c}173.32(121.1) \\
{[72.00-326.38]}\end{array}$ & $\begin{array}{c}15.52(8.31) \\
{[9.38-27.13]}\end{array}$ & $\begin{array}{c}5.27(4.77) \\
{[1.13-10.25]}\end{array}$ & $\begin{array}{c}0.69(0.80) \\
{[<0.29-1.50]}\end{array}$ & $\begin{array}{c}93.04(62.71) \\
{[47.25-181.88]}\end{array}$ \\
\hline Brussel sprout $^{7}$ & ud & $\begin{array}{c}0.45(0.78) \\
{[<0.14-1.35]}\end{array}$ & $\begin{array}{c}115.05(174.71) \\
{[1.60-316.25]}\end{array}$ & $\begin{array}{l}37.39(43.78) \\
{[1.31-86.10]}\end{array}$ & $\begin{array}{c}9.41(4.20) \\
{[4.60-12.38]}\end{array}$ & $\begin{array}{c}252.58(150.91) \\
{[114.31-} \\
413.56]\end{array}$ & $\begin{array}{c}17.08(7.97) \\
{[10.50-25.94]}\end{array}$ & $\begin{array}{c}2.97(2.65) \\
{[<0.08-5.10]}\end{array}$ & $\begin{array}{c}10.59(12.63) \\
{[<0.29-24.56]}\end{array}$ & $\begin{array}{c}166.58(43.09) \\
{[119.50-} \\
204.06]\end{array}$ \\
\hline Carrot $^{7}$ & ud & $\begin{array}{c}0.90(1.60) \\
{[<0.14-3.69]}\end{array}$ & $\begin{array}{c}12.13(16.88) \\
{[<0.06-41.25]}\end{array}$ & $\begin{array}{c}7.03(9.26) \\
{[<0.09-17.50]}\end{array}$ & $\begin{array}{c}1.88(1.93) \\
{[<0.35-4.38]}\end{array}$ & $\begin{array}{r}64.66(83.96) \\
{[4.25-186.63]}\end{array}$ & $\begin{array}{l}5.52(1.60) \\
{[3.10-7.50]}\end{array}$ & $\begin{array}{c}1.67(0.86) \\
{[0.44-2.38]}\end{array}$ & $\begin{array}{c}5.39(8.90) \\
{[<0.29-20.50]}\end{array}$ & $\begin{array}{c}23.35(31.95) \\
{[<0.07-61.19]}\end{array}$ \\
\hline Cauliflower ${ }^{7}$ & ud & $\begin{array}{c}0.52(0.25) \\
{[0.38-0.80]}\end{array}$ & $\begin{array}{l}91.98(110.97) \\
{[0.06-215.25]}\end{array}$ & $\begin{array}{l}32.22(50.23) \\
{[0.94-90.15]}\end{array}$ & $\begin{array}{c}1.38(2.40) \\
{[<0.35-4.15]}\end{array}$ & $\begin{array}{c}80.24(69.17) \\
{[26.75-158.35]}\end{array}$ & $\begin{array}{c}21.27(5.15) \\
{[17.44-27.13]}\end{array}$ & $\begin{array}{l}5.58(0.84) \\
{[4.60-6.06]}\end{array}$ & $\begin{array}{c}21.58(37.38) \\
{[<0.29-64.75]}\end{array}$ & $\begin{array}{c}46.23(77.28) \\
{[0.31-135.45]}\end{array}$ \\
\hline Celery $^{7}$ & ud & $\begin{array}{c}0.33(0.58) \\
{[<0.14-1.00]}\end{array}$ & $\begin{array}{c}58.29(20.18) \\
{[35.50-73.88]}\end{array}$ & $\begin{array}{c}25.33(21.94) \\
{[<0.09-38.38]}\end{array}$ & $\begin{array}{c}2.13(0.87) \\
{[1.63-3.13]}\end{array}$ & $\begin{array}{c}93.17(19.77) \\
{[70.50-106.88]}\end{array}$ & $\begin{array}{c}6.73(1.29) \\
{[5.38-7.94]}\end{array}$ & $\begin{array}{r}1.46(0.69) \\
{[1.00-2.25]}\end{array}$ & $\begin{array}{c}1.17(1.02) \\
{[<0.29-1.88]}\end{array}$ & $\begin{array}{l}51.69(13.23) \\
{[36.44-60.13]}\end{array}$ \\
\hline Champignon $^{7}$ & ud & $\begin{array}{c}6.73(1.03) \\
{[5.60-8.15]}\end{array}$ & $\begin{array}{c}1.40(3.07) \\
{[<0.06-6.90]}\end{array}$ & $<0.09$ & $\begin{array}{c}0.52(0.48) \\
{[<0.35-0.90]}\end{array}$ & $\begin{array}{c}1.93(1.59) \\
{[0.45-4.45]}\end{array}$ & $\begin{array}{c}74.58(18.71) \\
{[58.65-106.65]}\end{array}$ & $\begin{array}{c}2.10(0.55) \\
{[1.40-2.65]}\end{array}$ & $<0.29$ & $\begin{array}{l}38.56(37.11) \\
{[0.50-85.20]}\end{array}$ \\
\hline $\begin{array}{l}\text { Fermented lupine } \\
\text { brine }\end{array}$ & 1 & 0.05 & 0.40 & 0.67 & nd & 13.14 & 2.90 & 5.48 & & 0.21 \\
\hline Garlic $^{7}$ & ud & $\begin{array}{c}1.75(2.06) \\
{[<0.14-4.50]}\end{array}$ & $\begin{array}{c}8.46(7.84) \\
{[<0.06-17.69]}\end{array}$ & $\begin{array}{c}3.04(4.83) \\
{[<0.09-11.25]}\end{array}$ & $\begin{array}{c}0.69(1.22) \\
{[<0.35-2.81]}\end{array}$ & $\begin{array}{l}67.65(105.29) \\
{[4.25-249.44]}\end{array}$ & $\begin{array}{c}18.62(9.21) \\
{[8.31-33.06]}\end{array}$ & $\begin{array}{c}6.44(2.06) \\
{[3.94-9.40]}\end{array}$ & $\begin{array}{c}1.47(2.51) \\
{[<0.29-5.80]}\end{array}$ & $\begin{array}{c}8.44(7.75) \\
{[1.06-21.45]}\end{array}$ \\
\hline Pepper $^{7}$ & ud & $\begin{array}{c}2.48(0.50) \\
{[2.00-3.10]}\end{array}$ & $\begin{array}{c}0.08(0.15) \\
{[<0.06-0.30]}\end{array}$ & $<0.09$ & $\begin{array}{c}0.88(0.09) \\
{[0.75-0.95]}\end{array}$ & $\begin{array}{c}9.29(3.17) \\
{[6.45-13.80]}\end{array}$ & $\begin{array}{c}1.21(0.14) \\
{[1.10-1.40]}\end{array}$ & $\begin{array}{c}0.99(0.11) \\
{[0.90-1.15]}\end{array}$ & $<0.29$ & $\begin{array}{c}18.98(2.92) \\
{[15.65-22.75]}\end{array}$ \\
\hline Pickled caperberries ${ }^{11}$ & 9 & & $3.2(3.1)$ & $14.7(17.2)$ & & $13.1(8.5)$ & & $4.9(4.4)$ & & $1.6(2.6)$ \\
\hline Pickled capers ${ }^{11}$ & 8 & & nd & $8.2(6.7)$ & & $2.3(1.3)$ & & $2.3(2.4)$ & & $0.2(0.6)$ \\
\hline Pumpkin ${ }^{7}$ & ud & $\begin{array}{c}1.08(1.29) \\
{[<0.14-2.75]}\end{array}$ & $\begin{array}{c}20.97(0.76) \\
{[20.00-21.69]}\end{array}$ & $\begin{array}{l}29.58(31.13) \\
{[2.88-73.94]}\end{array}$ & $\begin{array}{c}1.13(1.44) \\
{[<0.35-3.00]}\end{array}$ & $\begin{array}{c}136.98(54.51) \\
{[55.44-169.13]}\end{array}$ & $\begin{array}{r}8.68(1.23) \\
{[7.06-9.75]}\end{array}$ & $\begin{array}{l}49.63(34.89) \\
{[2.00-83.20]}\end{array}$ & $\begin{array}{c}4.88(3.95) \\
{[<0.29-9.25]}\end{array}$ & $\begin{array}{c}62.61(39.09) \\
{[20.06-111.69]}\end{array}$ \\
\hline Radish $^{7}$ & ud & $\begin{array}{c}0.32(0.55) \\
{[<0.14-0.95]}\end{array}$ & $\begin{array}{l}14.18(20.27) \\
{[0.88-37.50]}\end{array}$ & $\begin{array}{l}22.37(22.04) \\
{[<0.09-44.06]}\end{array}$ & $\begin{array}{c}1.77(0.93) \\
{[0.75-2.56]}\end{array}$ & $\begin{array}{l}32.08(22.78) \\
{[6.38-49.80]}\end{array}$ & $\begin{array}{c}6.40(2.92) \\
{[4.40-9.75]}\end{array}$ & $\begin{array}{c}0.93(0.62) \\
{[0.45-1.63]}\end{array}$ & $\begin{array}{c}10.25(11.38) \\
{[<0.29-22.50]}\end{array}$ & $\begin{array}{l}22.50(11.33) \\
{[15.25-35.56]}\end{array}$ \\
\hline
\end{tabular}


Table 1. Cont.

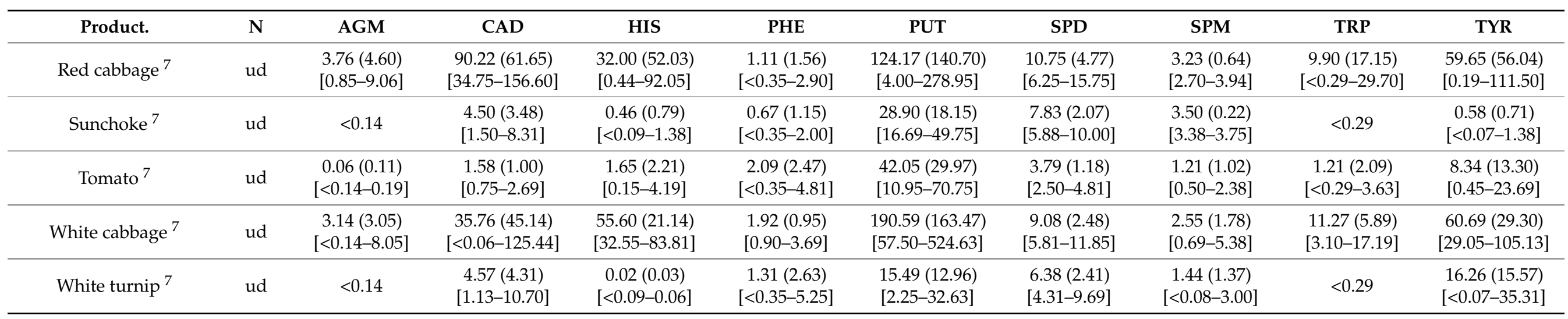

The average amounts of the biogenic amines are given. Standard deviation is given in parenthesis, and the range is given in square brackets. Amounts are given in mg/kg unless otherwise stated. CAD: cadaverine; DOP: dopamine; HIS: histamine; NOR: noradrenaline; PHE: 2-phenylethylamine; PUT: putrescine; SER: serotonin; SPD: spermidine; SPM: spermine; TRP: tryptamine; TYR: tyramine; N.: number of samples examined; ud: undefined; nd: not detected; tr: traces. ${ }^{1}$ Hornero-Mendez and Garrido-Fernandez [206] (in $\mu \mathrm{g} / \mathrm{mL}$ ); ${ }^{2}$ Garcia-Garcia et al. [207]; ${ }^{3}$ Moret et al. [194] (in mg/100 g fresh weight); ${ }^{4}$ Jin et al. [203]; ${ }^{5}$ Lee et al. [204]; ${ }^{6}$ Cho et al. [202]; ${ }^{7}$ Kang et al. [205]; ${ }^{8}$ Tsai et al. [201] (in mg/100 g);

${ }^{9}$ Shin et al. [208]; ${ }^{10}$ Swider et al. [200]; ${ }^{11}$ Kalac et al. [209]; ${ }^{2}$ Tofalo et al. [210]. 
The level of biogenic amines in sauerkraut was lower than that of kimchi, with the exception of tyramine (Table 1). In the latter case, Kalac et al. [209] analyzed 53 samples of Czech sauerkraut and reported the mean amount at $235 \mathrm{mg} / \mathrm{kg}$ and the highest amount at $951 \mathrm{mg} / \mathrm{kg}$. Reports on the biogenic amine content of fermented cucumbers and olives are generally lacking in the literature. Based on the available data (Table 1), fermented cucumbers seem to contain more biogenic amines than fermented olives but less than kimchi and sauerkraut. Regarding fermented olives, they seem to contain less biogenic amines than kimchi, sauerkraut, and fermented cucumbers. Regarding the rest of the fermented fruits and vegetables, the high amounts of agmatine $(6.73 \mathrm{mg} / \mathrm{kg})$ and spermidine $(74.58 \mathrm{mg} / \mathrm{kg})$ detected in champignon, of histamine $(55.60 \mathrm{mg} / \mathrm{kg})$ in white cabbage, of phenylethylamine $(9.41 \mathrm{mg} / \mathrm{kg})$, putrescine $(252.58 \mathrm{mg} / \mathrm{kg})$, and tyramine $(166.58 \mathrm{mg} / \mathrm{kg})$ in Brussels sprouts, of cadaverine $(119.42 \mathrm{mg} / \mathrm{kg})$ in broccoli, of spermine $(49.63 \mathrm{mg} / \mathrm{kg})$ in pumpkin, and of tryptamine $(21.58 \mathrm{mg} / \mathrm{kg})$ in cauliflower should be noticed (Table 1$)$.

The increase in the amount of biogenic amines in fermented foods compared to that of raw materials has been correlated with the microbiota that drive the fermentation. Indeed, the capacity of lactic acid bacteria to decarboxylate amino acids has been adequately exhibited [211]. However, it should be noted that this is a strain-dependent property. Thus, the haphazard nature of the biogenic amine content of spontaneously fermented fruits and vegetables is indicated. On the other hand, qualitative and quantitative control of biogenic amine production is an option that is offered when lactic acid fermentation is performed with the addition of starter cultures.

In the case of sauerkraut, the effect of raw materials on the production of biogenic amines has been highlighted by Majcherczyk et al. [212] and by Satora et al. [213]. In the latter study, eight cabbage varieties were employed to make sauerkraut through spontaneous fermentation; statistically significant differences in tyramine, histamine, cadaverine, putrescine, and tryptamine content were reported. Interestingly, a positive correlation between biogenic amine production and yeast presence was reported. The contribution of yeasts in the accumulation of biogenic amines is already known in products of alcoholic fermentation, such as wine [214]. The addition of ingredients that have an organoleptic impact, such as onion and caraway, affected the accumulation of some biogenic amines; the most pronounced effect was the reduced amounts of cadaverine and tyramine at the end of the 14-day fermentation period [212]. On the other hand, at the end of the 12-month storage at $4{ }^{\circ} \mathrm{C}$, the sauerkraut made at $18{ }^{\circ} \mathrm{C}$, with the addition of onion, accumulated significantly less cadaverine and phenethylamine compared to the control [212]. During spontaneous sauerkraut fermentation, the accumulation of biogenic amines seems to be affected by the aforementioned parameters, along with fermentation temperature and time. Indeed, Rabie et al. [215] reported an accumulation of histamine, tyramine, putrescine, and cadaverine after 10 days of fermentation at $15^{\circ} \mathrm{C}$, while Majcherczyk and Surowka [212] reported accumulation of cadaverine, tryptamine, and tyramine during fermentation at $18^{\circ} \mathrm{C}$ for $14 \mathrm{~d}$ and of putrescine and tryptamine during fermentation at $31^{\circ} \mathrm{C}$ for $14 \mathrm{~d}$. Similarly, accumulation during sauerkraut storage seems to be affected by the same parameters as above. Regarding the effect of cultivar, the accumulation pattern seems to be affected by the cabbage cultivar [216-218]; however, no details were provided on the capacity of the members of the microecosystem to perform amino acid decarboxylation. The addition of onion seemed to prohibit the accumulation of cadaverine and phenethylamine but only in sauerkraut fermented at $18^{\circ} \mathrm{C}$ and not $31^{\circ} \mathrm{C}$ [212]. The paramount effect of a lactic acid bacteria strain's decarboxylating capacity in the accumulation of biogenic amines has also been adequately exhibited. Indeed, statistically significant differences in the accumulation during storage were observed and assigned to the Lp. plantarum and Leu. mesenteroides strains that were used as inocula [219]. In addition, suppression of biogenic amine accumulation during fermentation and storage through inoculation with Lp. plantarum, Lt. curvatus, and La. casei was reported by Rabie et al. [215]. Interestingly, the importance of the interaction between the selected starter culture and the cabbage cultivar was highlighted by Kalac et al. [216] and Spicka et al. [220]. 
In the case of kimchi, the accumulation of biogenic amines during fermentation of four kimchi types, namely, Pa, Gat, Kkakdugi, and Chonggak, has been assessed. Lee et al. [204] prepared Pa and Gat kimchi and studied the effect of myeolchi-aekjeot, a fermented anchovy sauce, the addition of which has been correlated with increased biogenic amine content [202,221,222]; tyramine-producing Lv. brevis strains and Lp. plantarum strains were unable to produce biogenic amines. During fermentation of Pa and Gat kimchi, the amount of tryptamine and histamine was reduced. During Pa fermentation, accumulation of tyramine, putrescine, and cadaverine in all experimental cases was noted. Spermine was accumulated only in some cases, while $\beta$-phenylethylamine and spermidine amounts were stable throughout fermentation. During Gat fermentation, only the cadaverine amount remained unchanged throughout the fermentation, and the accumulation of tyramine, $\beta$-phenylethylamine, putrescine, and spermidine was recorded. Spermine was also accumulated but only in some cases. In general, the addition of myeolchi-aekjeot and the tyramine-producing Lv. brevis strain enhanced biogenic amine accumulation, with the exception of spermine. Jin et al. [203] prepared Kkakdugi and Chonggak kimchi and studied the effect of myeolchi-aekjeot and saeu-jeotgal, a fermented shrimp product, the utilization of which has also been correlated with increased biogenic amine levels [221] in tyramine-producing Lv. brevis strains and Lp. plantarum strains. During fermentation of both products, the histamine amount decreased and the spermidine amount increased. In the case of Kkakdugi, tyramine was accumulated only in the samples inoculated with $L v$. brevis, the putrescine amount slightly increased only in the uninoculated sample and the one inoculated with Lv. brevis JCM 1170, and cadaverine accumulated in all samples with the exception of the one that did not contain myeolchi-aekjeot, saeu-jeotgal, and inoculum. The latter sample was the only one in which spermine content increased, while in the rest, it was decreased. In the case of Chonggak, cadaverine remained stable in all samples but seemed to increase in the sample that did not contain the fermented fish condiments and inoculum; the tyramine amount increased in all samples with the exception of the one inoculated with Lp. plantarum, and cadaverine was accumulated only in the sample prepared with the addition of the fish condiments but without inoculum. In the same sample, along with the samples inoculated with Lv. brevis, the amount of spermine decreased. Combining the studies of Lee et al. [204] and Jin et al. [203], it can be concluded that the accumulation of biogenic amines could not always be predicted through the addition of ingredients that have been correlated with increased biogenic amine content (fish condiments) of starter cultures with known capacities. This indicates the existence of additional parameters that, at least in some cases, may affect biogenic amine accumulation. Since biogenic amine accumulation and decomposition are strain-dependent properties, it can be hypothesized that the native microbiota, and especially the proportion of which that manages to participate in the developing microecosystem, may be this additional parameter.

In the case of fermented cucumbers, biogenic amine accumulation during fermentation was assessed by Alan [223]. In the latter study, gherkin fermentation was performed spontaneously or with the addition of Lp. plantarum, Lp. pentosus, or L p paraplantarum strains as starter cultures. Spermidine was not detected in any experimental case. On the contrary, putrescine, cadaverine, histamine, and tyramine were detected, and their amount was strain-dependent. More accurately, spontaneously fermented gherkins contained an equal amount of putrescine with the one started with Lp. plantarum strain 49 , less than the one started with $L p$. plantarum strain 51, and more than the ones started with L $p$. plantarum strain 13, Lp. pentosus strain 2, and Lp. paraplantarum strain 16. Cadaverine and histamine were not accumulated in the gherkins started with all three Lp. plantarum strains, but larger amounts were detected in the gherkins started with Lp. pentosus strain 2 and $L p$. paraplantarum strain 16 compared to the spontaneously fermented ones. Finally, an equal amount of tyramine was accumulated in the gherkins started with Lp. plantarum strain 13 comapred with spontaneously fermented ones and larger amounts in the ones started with Lp. plantarum strains 49 and 51, Lp. pentosus strain 2, and Lp. paraplantarum strain 16. 
The fate of biogenic amines during the fermentation of olives of the Manzanilla cultivar was assessed by Garcia-Garcia et al. [224]. Putrescine, tryptamine, $\beta$-phenylethylamine, spermidine, spermine, histamine, and agmatine were not detected during storage at 15, 20, and $28{ }^{\circ} \mathrm{C}$ for 12 months. Only cadaverine and tyramine were accumulated. The former was produced only at 20 and $28{ }^{\circ} \mathrm{C}$, and the production rate increased after 7 and 5 months, respectively. Washing was correlated with increased production. Tyramine production followed a similar trend, with the exception that accumulation also occurred during storage at $15{ }^{\circ} \mathrm{C}$.

\section{Conclusions}

The functional potential of lactic acid fermented fruits and vegetables relies on the interplay between the quality of the raw materials and the capacity of the microbial consortium to carry out certain biotransformations. The former depends on the type and variety of the raw materials, climatic conditions, and agricultural practices, as well as the occurrence and conditions of processing and storage. On the other hand, the production of bioactive compounds by microorganisms is a strain-dependent characteristic that also depends on the fermentation temperature and time. Thus, optimization of the functional potential requires a thorough study of all the aforementioned parameters. Although a lot of information is available in some cases, e.g., the production of biogenic amines, the trophic relationships within the microecosystem are very complex, and, thus, further study is still necessary to enable practical recommendations.

Author Contributions: Conceptualization, S.P., G.D., H.-S.S., and J.K.P.; resources, S.P., G.D., H.-S.S., and J.K.P.; writing—original draft preparation, S.P., G.D., H.-S.S., and J.K.P.; writing—review and editing, S.P., G.D., H.-S.S., and J.K.P. All authors have read and agreed to the published version of the manuscript.

Funding: This work was supported by the National Research Foundation of Korea (NRF) through a grant funded by the Korean government (MSIT) (No. 2020R1G1A1004667), the Republic of Korea.

Institutional Review Board Statement: Not applicable.

Informed Consent Statement: Not applicable.

Data Availability Statement: All data related to this manuscript are presented in the form of tables and figures in the manuscript.

Acknowledgments: Authors are grateful to their respective institutions for support. G Das, HS Shin and JK Patra are grateful to Dongguk University, Republic of Korea for support. This work was supported by the National Research Foundation of Korea (NRF) through a grant funded by the Korean government (MSIT) (No. 2020R1G1A1004667), the Republic of Korea.

Conflicts of Interest: The authors declare no conflict of interest.

\section{References}

1. Ijarotimi, O.S.; Keshinro, O.O. Protein quality, hematological properties and nutritional status of albino rats fed complementary foods with fermented popcorn, African locust bean, and bambara groundnut flour blends. Nutr. Res. Pract. 2012, 6, 381-388. [CrossRef] [PubMed]

2. Oyewole, O.B. Lactic fermented foods in Africa and their benefits. Food Control 1997, 8, 289-297. [CrossRef]

3. Das, G.; Shin, H.-S.; Paramithiotis, S.; Sivamaruthi, B.S.; Wijaya, C.H.; Suharta, S.; Sanlier, N.; Patra, J.K. Traditional fermented foods with anti-aging effect: A concentric review. Food Res. Int. 2020, 134, 109269. [CrossRef]

4. Ishida, Y.; Nakamura, F.; Kanzato, H.; Sawada, D.; Yamamoto, N.; Kagata, H.; Oh-Ida, M.; Takeuchi, H.; Fujiwara, S. Effect of milk fermented with Lactobacillus acidophilus strain L-92 on symptoms of Japanese cedar pollen allergy: A randomized placebo-controlled trial. Biosci. Biotechnol. Biochem. 2005, 69, 1652-1660. [CrossRef] [PubMed]

5. Rosa, D.D.; Dias, M.M.; Grześkowiak, Ł.M.; Reis, S.A.; Conceição, L.L.; Maria do Carmo, G.P. Milk kefir: Nutritional, microbiological and health benefits. Nutr. Res. Rev. 2017, 30, 82-96. [CrossRef]

6. Mun, E.-G.; Sohn, H.-S.; Kim, M.-S.; Cha, Y.-S. Antihypertensive effect of Ganjang (traditional Korean soy sauce) on SpragueDawley rats. Nutr. Res. Pract. 2017, 11, 388-395. [CrossRef] [PubMed]

7. Kang, D.; Li, Z.; Ji, G.E. Anti-Obesity effects of a mixture of fermented ginseng, Bifidobacterium longum BORI, and Lactobacillus paracasei CH88 in high-fat diet-fed mice. J. Microbiol. Biotechnol. 2018, 28, 688-696. [CrossRef] 
8. Wang, L.-J.; Li, D.; Zou, L.; Dong Chen, X.; Cheng, Y.-Q.; Yamaki, K.; Li, L.-T. Antioxidative activity of douchi (a Chinese traditional salt-fermented soybean food) extracts during its processing. Int. J. Food Prop. 2007, 10, 385-396. [CrossRef]

9. Blana, V.A.; Grounta, A.; Tassou, C.C.; Nychas, G.J.; Panagou, E.Z. Lactobacillus pentosus and Lactobacillus plantarum starter cultures isolated from industrially fermented olives. Food Microbiol. 2014, 38, 208-218. [CrossRef]

10. Al-Shawi, S.G.; Swadi, W.A.; Hussein, A.A. Production of probiotic (Turshi) pickled vegetables. J. Pure Appl. Microbiol. 2019, 13, 2287-2293. [CrossRef]

11. Benitez-Cabello, A.; Torres-Maravilla, E.; Bermúdez-Humarán, L.; Langella, P.; Martín, R.; Jiménez-Díaz, R.; Arroyo-López, F.N. Probiotic properties of Lactobacillus strains isolated from table olive biofilms. Probiot. Antimicrob. 2020, 12, 1071-1082. [CrossRef] [PubMed]

12. Touret, T.; Oliveira, M.; Semedo-Lemsaddek, T. Putative probiotic lactic acid bacteria isolated from sauerkraut fermentations. PLoS ONE 2018, 13, e0203501. [CrossRef] [PubMed]

13. Jeong, C.-H.; Sohn, H.; Hwang, H.; Lee, H.-J.; Kim, T.-W.; Kim, D.-S.; Kim, C.-S.; Han, S.-G.; Hong, S.-W. Comparison of the probiotic potential between Lactiplantibacillus plantarum isolated from kimchi and standard probiotic strains isolated from different sources. Foods 2021, 10, 2125. [CrossRef] [PubMed]

14. Patra, J.K.; Das, G.; Paramithiotis, S.; Shin, H.S. Kimchi and other widely consumed traditional fermented foods of Korea: A review. Front. Microbiol. 2016, 7, 1493. [CrossRef] [PubMed]

15. Slavin, J.L.; Lloyd, B. Health benefits of fruits and vegetables. Adv. Nutr. 2012, 3, 506-516. [CrossRef]

16. Burgess, C.M.; Smid, E.J.; Rutten, G.; van Sinderen, D. A general method for selection of riboflavin-overproducing food grade micro-organisms. Microb. Cell Factories 2006, 5, 24. [CrossRef]

17. Ewe, J.-A.; Wan-Abdullah, W.-N.; Liong, M.-T. Viability and growth characteristics of Lactobacillus in soymilk supplemented with B-vitamins. Int. J. Food Sci. Nutr. 2010, 61, 87-107. [CrossRef]

18. Capozzi, V.; Menga, V.; Digesu, A.M.; De Vita, P.; Van Sinderen, D.; Cattivelli, L.; Fares, C.; Spano, G. Biotechnological production of vitamin B2-enriched bread and pasta. J. Agric. Food Chem. 2011, 59, 8013-8020. [CrossRef]

19. Juarez del Valle, M.; Laino, J.E.; Savoy de Giori, G.; LeBlanc, J.G. Riboflavin producing lactic acid bacteria as a biotechnological strategy to obtain bioenriched soymilk. Food Res. Int. 2014, 62, 1015-1019. [CrossRef]

20. Thakur, K.; Lule, V.K.; Rajni, C.S.; Kumar, N.; Mandal, S.; Anand, S.; Kumari, V.; Tomar, S.K. Riboflavin producing probiotic Lactobacilli as a biotechnological strategy to obtain riboflavin-enriched fermented foods. J. Pure Appl. Microbiol. 2016, 10, 161-166.

21. Hati, S.; Patel, M.; Mishra, B.K.; Das, S. Short-chain fatty acid and vitamin production potentials of Lactobacillus isolated from fermented foods of Khasi Tribes, Meghalaya, India. Ann. Microbiol. 2019, 69, 1191-1199. [CrossRef]

22. Yepez, A.; Russo, P.; Spano, G.; Khomenko, I.; Biasioli, F.; Capozzi, V.; Aznar, R. In situ riboflavin fortification of different kefir-like cereal-based beverges using selected andean LAB strains. Food Microbiol. 2019, 77, 61-68. [CrossRef] [PubMed]

23. Sabo, S.S.; Mendes, M.A.; Araújo, E.S.; Muradian, L.B.A.; Makiyama, E.N.; LeBlanc, J.G.; Borelli, P.; Fock, R.A.; Knobl, T.; Oliveira, R.P.S. Bioprospecting of probiotics with antimicrobial activities against Salmonella Heidelberg and that produce B-complex vitamins as potential supplements in poultry nutrition. Sci. Rep. 2020, 10, 7235. [CrossRef] [PubMed]

24. Gangadharan, D.; Nampoothiri, K. Folate production using Lactococcus lactis ssp cremoris with implications for fortification of skim milk and fruit juices. LWT-Food Sci. Technol. 2011, 44, 1859-1864. [CrossRef]

25. Laino, J.E.; LeBlanc, J.G.; Savoy de Giori, G. Production of natural folates by lactic acid bacteria starter cultures isolated from artisanal Argentinean yogurts. Can. J. Microbiol. 2012, 58, 581-588. [CrossRef]

26. Carrizo, S.L.; Montes de Oca, C.E.; Hebert, M.E.; Saavedra, L.; Vignolo, G.; LeBlanc, J.G.; Rollan, G.C. Lactic acid bacteria from andean grain amaranth: A source of vitamins and functional value enzymes. J. Mol. Microbiol. Biotechnol. 2017, 27, 289-298. [CrossRef]

27. Meucci, A.; Rossetti, L.; Zago, M.; Monti, L.; Giraffa, G.; Carminati, D.; Tidona, F. Folates biosynthesis by Streptococcus thermophilus during growth in milk. Food Microbiol. 2018, 69, 116-122. [CrossRef]

28. Tamene, A.; Baye, K.; Kariluoto, S.; Edelmann, M.; Bationo, F.; Leconte, N.; Humblot, C. Lactobacillus plantarum P2R3FA isolated from traditional cereal-based fermented food increase folate status in deficient rats. Nutrients 2019, 11, 2819. [CrossRef]

29. Taranto, M.; Vera, J.; Hugenholtz, J.; De Valdez, G.; Sesma, F. Lactobacillus reuteri CRL1098 produces cobalamin. J. Bacteriol. 2003, 185, 5643-5647. [CrossRef]

30. Masuda, M.; Ide, M.; Utsumi, H.; Niiro, T.; Shimamura, Y.; Murata, M. Production potency of folate, vitamin B12 and thiamine by lactic acid bacteria isolated from Japanese pickles. Biosci. Biotechnol. Biochem. 2012, 76, 2061-2067. [CrossRef]

31. de Angelis, M.; Bottacini, F.; Fosso, B.; Kelleher, P.; Calasso, M.; Di Cagno, R.; Ventura, M.; Picardi, E.; van Sinderen, D.; Gobbetti, M. Lactobacillus rossiae, a vitamin B12 producer, represents a metabolically versatile species within the genus Lactobacillus. PLoS ONE 2014, 9, e107232. [CrossRef] [PubMed]

32. Torres, A.C.; Vannini, V.; Bonacina, J.; Font, G.; Saavedra, L.; Taranto, M.P. Cobalamin production by Lactobacillus coryniformis: Biochemical identification of the synthetized corrinoid and genomic analysis of the biosynthetic cluster. BMC Microbiol. 2016, 16, 240. [CrossRef]

33. Li, P.; Gu, Q.; Wang, Y.; Yu, Y.; Yang, L.; Chen, J.V. Novel vitamin B12-producing Enterococcus spp. and preliminary in vitro evaluation of probiotic potentials. Appl. Microbiol. Biotechnol. 2017, 101, 6155-6164. [CrossRef] [PubMed]

34. Li, P.; Gu, Q.; Yang, L.; Yu, Y.; Wang, Y. Characterization of extracellular vitamin B12 producing Lactobacillus plantarum strains and assessment of the probiotic potentials. Food Chem. 2017, 234, 494-501. [CrossRef] 
35. Hati, S.; Patel, N.; Sakure, A.; Mandal, S. Influence of whey protein concentrate on the production of antibacterial peptides derived from fermented milk by lactic acid bacteria. Int. J. Pept. Res. Ther. 2018, 24, 87-98. [CrossRef]

36. Hamzehlou, P.; Sepahy, A.A.; Mehrabian, S.; Hosseini, F. Production of vitamins B3, B6 and B9 by Lactobacillus isolated from traditional yogurt samples from 3 cities in Iran, winter 2016. Appl. Food Biotechnol. 2018, 5, 107-120.

37. Liu, Y.; van Bennekom, E.O.; Zhang, Y.; Abee, T.; Smid, E.J. Long-chain vitamin K2 production in Lactococcus lactis is influenced by temperature, carbon source, aeration and mode of energy metabolism. Microb. Cell Factories 2019, 18, 129. [CrossRef]

38. Teran, M.M.; LeBlanc, A.M.; Giori, G.S.; LeBlanc, J.G. Thiamine-producing lactic acid bacteria and their potential use in the prevention of neurodegenerative diseases. Appl. Microbiol. Biotechnol. 2021, 105, 2097-2107. [CrossRef]

39. Delchier, N.; Herbig, A.-L.; Rychlik, M.; Renard, C.M.G.C. Folates in fruits and vegetables: Contents, processing, and stability. Compr. Rev. Food Sci. Food Saf. 2016, 15, 506-528. [CrossRef]

40. Powers, H.J. Riboflavin (vitamin B-2) and health. Am. J. Clin. Nutr. 2003, 77, 1352-1360. [CrossRef]

41. Jagerstad, M.; Jastrebova, J.; Svensson, U. Folates in fermented vegetables-A pilot study. LWT-Food Sci. Technol. 2004, 37, 603-611. [CrossRef]

42. Thompson, H.O.; Onning, G.; Holmgren, K.; Strandler, H.S.; Hultberg, M. Fermentation of cauliflower and white beans with Lactobacillus plantarum - Impact on levels of riboflavin, folate, vitamin B12 and amino acid composition. Plant Foods Hum. Nutr. 2020, 75, 236-242. [CrossRef] [PubMed]

43. Kinnersley, A.M.; Turano, F.J. Gamma aminobutyric acid (GABA) and plant responses to stress. Crit. Rev. Plant Sci. 2000, 19, 479-509. [CrossRef]

44. Podlesakova, K.; Ugena, L.; Spichal, L.; Dolezal, K.; De Diego, N. Phytohormones and polyamines regulate plant stress responses by altering GABA pathway. New Biotechnol. 2019, 48, 53-65. [CrossRef] [PubMed]

45. Ramos-Ruiz, R.; Martinez, F.; Knauf-Beiter, G. The effects of GABA in plants. Cogent Food Agric. 2019, 5, 1670553. [CrossRef]

46. Hepsomali, P.; Groeger, J.A.; Nishihira, J.; Scholey, A. Effects of oral gamma-aminobutyric acid (GABA) administration on stress and sleep in humans: A systematic review. Front. Neurosci. 2020, 14, 923. [CrossRef]

47. Abdou, A.M.; Higashiguchi, S.; Horie, K.; Kim, M.; Hatta, H.; Yokogoshi, H. Relaxation and immunity enhancement effects of gamma aminobutyric acid (GABA) administration in humans. Biofactors 2006, 26, 201-208. [CrossRef]

48. Yoto, A.; Murao, S.; Motoki, M.; Yokoyama, Y.; Horie, N.; Takeshima, K.; Masuda, K.; Kim, M.; Yokogoshi, H. Oral intake of g-aminobutyric acid affects mood and activities of central nervous system during stressed condition induced by mental tasks. Amino Acids 2012, 43, 1331-1337. [CrossRef]

49. Yamatsu, A.; Yamashita, Y.; Pandharipande, T.; Maru, I.; Kim, M. Effect of oral gamma-aminobutyric acid (GABA) administration on sleep and its absorption in humans. Food Sci. Biotechnol. 2016, 25, 547-551. [CrossRef]

50. Cotter, P.D.; Hill, C. Surviving the acid test: Responses of gram-positive bacteria to low pH. Microbiol. Mol. Biol. Rev. 2003, 67, 429-453. [CrossRef]

51. Hao, R.; Schmit, J.C. Cloning of the gene for glutamate decarboxylase and its expression during conidiation in Neurospora crassa. Biochem. J. 1993, 293, 735-738. [CrossRef] [PubMed]

52. Foester, C.W.; Foester, H.F. Glutamic acid decarboxylase in spores of Bacillus megaterium and its possible involvement in spore germination. J. Bacteriol. 1973, 114, 1090-1098. [CrossRef] [PubMed]

53. Wu, Q.; Tun, H.M.; Law, Y.-S.; Khafipour, E.; Shah, N.P. Common distribution of gad operon in Lactobacillus brevis and its GadA contributes to efficient GABA synthesis toward cytosolic near-neutral pH. Front. Microbiol. 2017, 8, 206. [CrossRef] [PubMed]

54. Siragusa, S.; De Angelis, M.; Di Cagno, R.; Rizzello, C.G.; Coda, R.; Gobbetti, M. Synthesis of $\gamma$-aminobutyric acid by lactic acid bacteria isolated from a variety of Italian cheeses. Appl. Environ. Microbiol. 2007, 73, 7283-7290. [CrossRef]

55. Lim, H.S.; Cha, I.-T.; Roh, S.W.; Shin, H.-H.; Seo, M.-J. Enhanced production of gamma-aminobutyric acid by optimizing culture conditions of Lactobacillus brevis HYE1 isolated from kimchi, a Korean fermented food. J. Microbiol. Biotechnol. 2017, 27, 450-459. [CrossRef]

56. Han, M.; Liao, W.-Y.; Wu, S.-M.; Gong, X.; Bai, C. Use of Streptococcus thermophilus for the in situ production of $\gamma$-aminobutyric acid-enriched fermented milk. J. Dairy Sci. 2020, 103, 98-105. [CrossRef]

57. Ramos-Ruiz, R.; Poirot, E.; Flores-Mosquera, M. GABA, a non-protein amino acid ubiquitous in food matrices. Cogent Food Agric. 2018, 4, 1534323. [CrossRef]

58. Stines, A.P.; Grubb, J.; Gockowiak, H.; Henschke, P.A.; Høj, P.B.; Heeswijck, R. Proline and arginine accumulation in developing berries of Vitis vinifera L. in Australian vineyards: Influence of vine cultivar, berry maturity and tissue type. Aust. J. Grape Wine Res. 2000, 6, 150-158. [CrossRef]

59. Oh, S.-H.; Moon, Y.-J.; Oh, C.-H. $\gamma$-aminobutyric acid (GABA) content of selected uncooked foods. Nutraceutical Food 2003, 8 , 75-78. [CrossRef]

60. Zazzeroni, R.; Homan, A.; Thain, E. Determination of gamma-Aminobutyric acid in food matrices by isotope dilution hydrophilic interaction chromatography coupled to mass spectrometry. J. Chromatogr. Sci. 2009, 47, 564-568. [CrossRef]

61. Choi, S.W.; Kim, E.O.; Lee, Y.J.; Leem, H.H.; Seo, I.H.; Yu, M.H.; Kang, D.H. Comparison of nutritional and functional constituents, and physicochemical characteristics of mulberrys from seven different Morus alba L. cultivars. J. Korean Soc. Food Sci. Nutr. 2010, $39,1467-1475$. 
62. Sanchez-Hernandez, L.; Marina, M.L.; Crego, A.L. A capillary electrophoresis-Tandem mass spectrometry methodology for the determination of non-protein amino acids in vegetable oils as novel markers for the detection of adulterations in olive oils. $J$. Chromatogr. A 2011, 1218, 4944-4951. [CrossRef] [PubMed]

63. Rosati, A.; Cafiero, C.; Paoletti, A.; Alfei, B.; Caporali, S.; Casciani, L.; Valentini, M. Effect of agronomical practices on carpology, fruit and oil composition, and oil sensory properties, in olive (Olea europaea L.). Food Chem. 2014, 159, 236-243. [CrossRef] [PubMed]

64. Cha, Y.-S.; Oh, S.-H. Investigation of $\gamma$-aminobutyric acid in Chinese cabbages and effects of the cabbage diets on lipid metabolism and liver function of rats administered with ethanol. J. Korean Soc. Food Sci. Nutr. 2000, 29, 500-505.

65. Moore, J.F.; DuVivier, R.; Johanningsmeier, S.D. Formation of $\gamma$-aminobutyric acid (GABA) during the natural lactic acid fermentation of cucumber. J. Food Compos. Anal. 2021, 96, 103711. [CrossRef]

66. Bonatsou, S.; Iliopoulos, V.; Mallouchos, A.; Gogou, E.; Oikonomopoulou, V.; Krokida, M.; Taoukis, P.; Panagou, E.Z. Effect of osmotic dehydration of olives as pre-fermentation treatment and partial substitution of sodium chloride by monosodium glutamate in the fermentation profile of Kalamata natural black olives. Food Microbiol. 2017, 63, 72-83. [CrossRef]

67. Jeong, S.H.; Lee, S.H.; Jung, J.Y.; Choi, E.J.; Jeon, C.O. Microbial succession and metabolite changes during long-term storage of Kimchi. J. Food Sci. 2013, 78, M763-M769. [CrossRef]

68. Seok, J.-H.; Park, K.-B.; Kim, Y.-H.; Bae, M.-O.; Lee, M.-K.; Oh, S.-H. Production and characterization of kimchi with enhanced levels of $\gamma$-aminobutyric acid. Food Sci. Biotechnol. 2008, 17, 940-946.

69. Cho, S.Y.; Park, M.J.; Kim, K.M.; Ryu, J.-H.; Park, H.J. Production of high $\gamma$-aminobutyric acid (GABA) sour kimchi using lactic acid bacteria isolated from mukeunjee kimchi. Food Sci. Biotechnol. 2011, 20, 403-408. [CrossRef]

70. Lee, K.W.; Shim, J.M.; Yao, Z.; Kim, J.A.; Kim, J.H. Properties of kimchi fermented with GABA-producing lactic acid bacteria as a starter. J. Microbiol. Biotechnol. 2018, 28, 534-541. [CrossRef]

71. Savijoki, K.; Ingmer, H.; Varmanen, P. Proteolytic systems of lactic acid bacteria. Appl. Microbiol. Biotechnol. 2006, 71, 394-406. [CrossRef] [PubMed]

72. Rutella, G.S.; Tagliazucchi, D.; Solieri, L. Survival and bioactivities of selected probiotic lactobacilli in yogurt fermentation and cold storage: New insights for developing a bi-functional dairy food. Food Microbiol. 2016, 60, 54-61. [CrossRef] [PubMed]

73. Aguilar-Toala, J.E.; Santiago-Lopez, L.; Peres, C.M.; Peres, C.; Garcia, H.S.; Vallejo-Cordoba, B.; Gonzalez-Cordova, A.F.; Hernandez-Mendoza, A. Assessment of multifunctional activity of bioactive peptides derived from fermented milk by specific Lactobacillus plantarum strains. J. Dairy Sci. 2017, 100, 65-75. [CrossRef] [PubMed]

74. Skrzypczak, K.W.; Gustaw, W.Z.; Jabłonska-Ryś, E.D.; Michalak-Majewska, M.; Sławińska, A.; Radzki, W.P.; Gustaw, K.M.; Waśko, A.D. Antioxidative properties of milk protein preparations fermented by Polish strains of Lactobacillus helveticus. Acta Sci. Pol. Technol. Aliment. 2017, 16, 199-207. [CrossRef]

75. Taha, S.; El Abd, M.; De Gobba, C.; Abdel-Hamid, M.; Khalil, E.; Hassan, D. Antioxidant and antibacterial activities of bioactive peptides in buffalo's yoghurt fermented with different starter cultures. Food Sci. Biotechnol. 2017, 26, 1325-1332. [CrossRef]

76. El-Fattah, A.A.; Sakr, S.; El-Dieb, S.; Elkashef, H. Developing functional yogurt rich in bioactive peptides and gamma aminobutyric acid related to cardiovascular health. LWT-Food Sci. Technol. 2018, 98, 390-397. [CrossRef]

77. Ayyash, M.; Liu, S.Q.; Al Mheiri, A.; Aldhaheri, M.; Raeisi, B.; Al-Nabulsi, A.; Osaili, T.; Olaimat, A. In vitro investigation of health-promoting benefits of fermented camel sausage by novel probiotic Lactobacillus plantarum: A comparative study with beef sausages. LWT-Food Sci. Technol. 2019, 99, 346-354. [CrossRef]

78. Cao, C.C.; Feng, M.Q.; Sun, J.; Xu, X.L.; Zhou, G.H. Screening of lactic acid bacteria with high protease activity from fermented sausages and antioxidant activity assessment of its fermented sausages. CyTA-J. Food 2019, 17, 347-354. [CrossRef]

79. Sanchez-Lopez, F.; Robles-Olvera, V.J.; Hidalgo-Morales, M.; Tsopmo, A. Characterization of Amaranthus hypochondriacus seed protein fractions, and their antioxidant activity after hydrolysis with lactic acid bacteria. J. Cereal Sci. 2020, 95, 103075. [CrossRef]

80. Worsztynowicz, P.; Białas, W.; Grajek, W. Integrated approach for obtaining bioactive peptides from whey proteins hydrolysed using a new proteolytic lactic acid bacteria. Food Chem. 2020, 312, 126035. [CrossRef]

81. Luti, S.; Mazzoli, L.; Ramazzotti, M.; Galli, V.; Venturi, M.; Marino, G.; Lehmann, M.; Guerrini, S.; Granchi, L.; Paoli, P.; et al. Antioxidant and anti-inflammatory properties of sourdoughs containing selected Lactobacilli strains are retained in breads. Food Chem. 2020, 322, 126710. [CrossRef] [PubMed]

82. Ademiluyi, A.O.; Oboh, G. Angiotensin I-converting enzyme inhibitory activity and hypocholesterolemic effect of some fermented tropical legumes in streptozotocin-induced diabetic rats. Int. J. Diabetes Dev. Ctries. 2015, 35, 493-500. [CrossRef]

83. Ebner, J.; Aşci Arslan, A.; Fedorova, M.; Hoffmann, R.; Kucukcetin, A.; Pischetsrieder, M. Peptide profiling of bovine kefir reveals 236 unique peptides released from caseins during its production by starter culture or kefir grains. J. Proteom. 2015, 117, 41-57. [CrossRef] [PubMed]

84. Dallas, D.C.; Citerne, F.; Tian, T.; Silva, V.L.M.; Kalanetra, K.M.; Frese, S.A.; Robinson, R.C.; Mills, D.A.; Barile, D. Peptidomic analysis reveals proteolytic activity of kefir microorganisms on bovine milk proteins. Food Chem. 2016, 197, 273-284. [CrossRef]

85. Sah, B.N.P.; Vasiljevic, T.; McKechnie, S.; Donkor, O.N. Antioxidant peptides isolated from synbiotic yoghurt exhibit antiproliferative activities against HT-29 colon cancer cells. Int. Dairy J. 2016, 63, 99-106. [CrossRef]

86. Izquierdo-Gonzalez, J.J.; Amil-Ruiz, F.; Zazzu, S.; Sanchez-Lucas, R.; Fuentes-Almagro, C.A.; Rodriguez-Ortega, M.J. Proteomic analysis of goat milk kefir: Profiling the fermentation time dependent protein digestion and identification of potential peptides with biological activity. Food Chem. 2019, 295, 456-465. [CrossRef] 
87. Mushtaq, M.; Gani, A.; Masoodi, F.A. Himalayan cheese (Kalari/Kradi) fermented with different probiotic strains: In vitro investigation of nutraceutical properties. LWT-Food Sci. Technol. 2019, 104, 53-60. [CrossRef]

88. Gallego, M.; Mora, L.; Escudero, E.; Toldra, F. Bioactive peptides and free amino acids profiles in different types of European dry-fermented sausages. Int. J. Food Microbiol. 2018, 276, 71-78. [CrossRef]

89. Wu, H.; Rui, X.; Li, W.; Xiao, Y.; Zhou, J.; Dong, M. Whole grain oats (Avena sativa L.) as a carrier of lactic acid bacteria and a supplement rich in angiotensin I-converting enzyme inhibitory peptides through solid-state fermentation. Food Funct. 2018, 9 , 2270-2281. [CrossRef]

90. Ayyash, M.; Johnson, S.K.; Liu, S.Q.; Mesmari, N.; Dahmani, S.; Al Dhaheri, A.S.; Kizhakkayil, J. In vitro investigation of bioactivities of solid-state fermented lupin, quinoa and wheat using Lactobacillus spp. Food Chem. 2019, 275, 50-58. [CrossRef]

91. Sosalagere, C.; Kehinde, B.A.; Sharma, P. Isolation and functionalities of bioactive peptides from fruits and vegetables: A review. Food Chem. 2022, 366, 130494. [CrossRef] [PubMed]

92. Vasquez-Villanueva, R.; Muñoz-Moreno, L.; Carmena, M.J.; Marina, M.L.; García, M.C. In vitro antitumor and hypotensive activity of peptides from olive seeds. J. Funct. Foods 2018, 42, 177-184. [CrossRef]

93. Fideler, J.; Johanningsmeier, S.D.; Ekelof, M.; Muddiman, D.C. Discovery and quantification of bioactive peptides in fermented cucumber by direct analysis IR-MALDESI mass spectrometry and LC-QQQ-MS. Food Chem. 2019, 271, 715-723. [CrossRef] [PubMed]

94. Isabelle, M.; Lee, B.L.; Lim, M.T.; Koh, W.-P.; Huang, D.; Ong, C.N. Antioxidant activity and profiles of common vegetables in Singapore. Food Chem. 2010, 120, 993-1003. [CrossRef]

95. Ozcan, M.M.; Fındık, S.; AlJuhaimi, F.; Ghafoor, K.; Babiker, E.E.; Adiamo, O.Q. The effect of harvest time and varieties on total phenolics, antioxidant activity and phenolic compounds of olive fruit and leaves. J. Food Sci. Technol. 2019, 56, 2373-2385. [CrossRef]

96. Septembre-Malaterre, A.; Remize, F.; Poucheret, P. Fruits and vegetables, as a source of nutritional compounds and phytochemicals: Changes in bioactive compounds during lactic fermentation. Food Res. Int. 2018, 104, 86-99. [CrossRef] [PubMed]

97. Babenko, L.M.; Smirnov, O.E.; Romanenko, K.O.; Trunova, O.K.; Kosakivska, I.V. Phenolic compounds in plants: Biogenesis and functions. Ukr. Biochem. J. 2019, 91, 5-18. [CrossRef]

98. Landete, J.M. Updated knowledge about polyphenols: Functions, bioavailability, metabolism, and health. Crit. Rev. Food Sci. Nutr. 2012, 52, 936-948. [CrossRef]

99. Ciniviz, M.; Yildiz, H. Determination of phenolic acid profiles by HPLC in lacto-fermented fruits and vegetables (pickle): Effect of pulp and juice portions. J. Food Process. Preserv. 2020, 44, e14542. [CrossRef]

100. Munoz, R.; de las Rivas, B.; López de Felipe, F.; Reverón, I.; Santamaría, L.; Esteban-Torres, M.; Curiel, J.A.; Rodríguez, H.; Landete, J.M. Biotransformation of phenolics by Lactobacillus plantarum in fermented foods. In Fermented Foods in Health and Disease Prevention; Frias, J., Martinez-Villaluenga, C., Peñas, E., Eds.; Academic Press: London, UK, 2017; pp. $63-83$.

101. Donkor, O.N.; Shah, N. Production of beta-glucosidase and hydrolysis of isoflavone phytoestrogens by Lactobacillus acidophilus, Bifidobacterium lactis, and Lactobacillus casei in soymilk. J. Food Sci. 2008, 73, M15-M20. [CrossRef] [PubMed]

102. Rekha, C.R.; Vijayalakshmi, G. Isoflavone phytoestrogens in soymilk fermented with betaglucosidase producing probiotic lactic acid bacteria. Int. J. Food Sci. Nutr. 2011, 62, 111-120. [CrossRef] [PubMed]

103. Zago, M.; Lanza, B.; Rossetti, L.; Muzzalupo, I.; Carminati, D.; Giraffa, G. Selection of Lactobacillus plantarum strains to use as starters in fermented table olives: Oleuropeinase activity and phage sensitivity. Food Microbiol. 2013, 34, 81-87. [CrossRef] [PubMed]

104. Barthelmebs, L.; Divies, C.; Cavin, J.-F. Knockout of the p-coumarate decarboxylase gene from Lactobacillus plantarum reveals the existence of two other inducible enzymatic activities involved in phenolic acid metabolism. Appl. Environ. Microbiol. 2000, 66, 3368-3375. [CrossRef] [PubMed]

105. Rodrigues, H.; Landete, J.M.; Curiel, J.A.; de las Rivas, B.; Mancheno, J.M.; Munoz, R. Characterization of the p-coumaric acid decarboxylase from Lactobacillus plantarum CECT 748T. J. Agric. Food Chem. 2008, 56, 3068-3072. [CrossRef] [PubMed]

106. Malheiro, R.; Mendes, P.; Fernandes, F.; Rodrigues, N.; Bento, A.; Pereira, J.A. Bioactivity and phenolic composition from natural fermented table olives. Food Funct. 2014, 5, 3132-3142. [CrossRef] [PubMed]

107. Kaltsa, A.; Papaliaga, D.; Papaioannou, E.; Kotzekidou, P. Characteristics of oleuropeinolytic strains of Lactobacillus plantarum group and influence on phenolic compounds in table olives elaborated under reduced salt conditions. Food Microbiol. 2015, 48, 58-62. [CrossRef]

108. Pistarino, E.; Aliakbarian, B.; Casazza, A.A.; Paini, M.; Cosulich, M.E.; Perego, P. Combined effect of starter culture and temperature on phenolic compounds during fermentation of Taggiasca black olives. Food Chem. 2013, 138, 2043-2049. [CrossRef]

109. Benincasa, C.; Muccilli, S.; Amenta, M.; Perri, E.; Romeo, F.V. Phenolic trend and hygienic quality of green table olives fermented with Lactobacillus plantarum starter culture. Food Chem. 2015, 186, 271-276. [CrossRef]

110. Durante, M.; Tufariello, M.; Tommasi, L.; Lenucci, M.S.; Bleve, G.; Mita, G. Evaluation of bioactive compounds in black table olives fermented with selected microbial starters. J. Sci. Food Agric. 2018, 98, 96-103. [CrossRef] [PubMed]

111. Park, J.-M.; Shin, J.-H.; Gu, J.-G.; Yoon, S.-J.; Song, J.-C.; Jeon, W.-M.; Suh, H.-J.; Chang, U.-J.; Yang, C.-Y.; Kim, J.-M. Effect of antioxidant activity in kimchi during a short-term and over-ripening fermentation period. J. Biosci. Bioeng. 2011, 112, 356-359. [CrossRef] 
112. Park, S.-Y.; Jang, H.-L.; Lee, J.-H.; Choi, Y.; Kim, H.; Hwang, J.; Seo, D.; Kim, S.; Nam, J.-S. Changes in the phenolic compounds and antioxidant activities of mustard leaf (Brassica juncea) kimchi extracts during different fermentation periods. Food Sci. Biotechnol. 2017, 26, 105-112. [CrossRef] [PubMed]

113. Oh, S.K.; Tsukamoto, C.; Kim, K.W.; Choi, M.R. Investigation of glucosinolates, and the antioxidant activity of Dolsan leaf mustard kimchi extract using HPLC and LC-PDA-MS/MS. J. Food Biochem. 2017, 41, e12366. [CrossRef]

114. Jung, S.J.; Kim, M.J.; Chae, S.W. Quality and functional characteristics of kimchi made with organically cultivated young Chinese cabbage (olgari-baechu). J. Ethn. Foods 2016, 3, 150-158. [CrossRef]

115. Ciska, E.; Karamac, M.; Kosinska, A. Antioxidant activity of extracts of white cabbage and sauerkraut. Pol. J. Food Nutr. Sci. 2005, 55, 367-373.

116. Kapusta-Duch, J.; Kusznierewicz, B.; Leszczyńska, T.; Borczak, B. Effect of package type on selected parameters of nutritional quality of chill-stored white sauerkraut. Pol. J. Food Nutr. Sci. 2017, 67, 137-144. [CrossRef]

117. Degrain, A.; Manhivi, V.; Remize, F.; Garcia, C.; Sivakumar, D. Effect of lactic acid fermentation on color, phenolic compounds and antioxidant activity in African Nightshade. Microorganisms 2020, 8, 1324. [CrossRef] [PubMed]

118. Zhou, Y.; Wang, R.; Zhang, Y.; Yang, Y.; Sun, X.; Zhang, Q.; Yang, N. Biotransformation of phenolics and metabolites and the change in antioxidant activity in kiwifruit induced by Lactobacillus plantarum fermentation. J. Sci. Food Agric. 2020, 100, 3283-3290. [CrossRef]

119. Halkier, B.A.; Gershenzon, J. Biology and biochemistry of glucosinolates. Annu. Rev. Plant Biol. 2006, 57, 303-333. [CrossRef] [PubMed]

120. Williams, D.J.; Critchley, C.; Pun, S.; Chaliha, M.; O'Hare, T.J. Differing mechanisms of simple nitrile formation on glucosinolate degradation in Lepidium sativum and Nasturtium officinale seeds. Phytochemistry 2009, 70, 1401-1409. [CrossRef]

121. Lee, M.-K.; Chun, J.-H.; Byeon, D.H.; Chung, S.-O.; Park, S.U.; Park, S.; Arasu, M.V.; Al-Dhabi, N.A.; Lim, Y.-P.; Kim, S.-J. Variation of glucosinolates in 62 varieties of Chinese cabbage (Brassica rapa L. ssp. pekinensis) and their antioxidant activity. LWT-Food Sci. Technol. 2014, 58, 93-101. [CrossRef]

122. Martinez-Ballesta, M.C.; Moreno, D.A.; Carvajal, M. The physiological importance of glucosinolates on plant response to abiotic stress in Brassica. Int. J. Mol. Sci. 2013, 14, 11607-11625. [CrossRef] [PubMed]

123. Bischoff, K. Glucosinolates and organosulfur compounds. In Nutraceuticals in Veterinary Medicine; Gupta, R.C., Srivastava, A., Lall, R., Eds.; Springer Nature: Cham, Switzerland, 2019; pp. 113-119.

124. Barba, F.J.; Nikmaram, N.; Roohinejad, S.; Khelfa, A.; Zhu, Z.; Koubaa, M. Bioavailability of glucosinolates and their breakdown products: Impact of processing. Front. Nutr. 2016, 3, 24. [CrossRef] [PubMed]

125. Martinez-Villaluenga, C.; Peñas, E.; Frias, J.; Ciska, E.; Honke, J.; Piskula, M.K.; Kozlowska, H.; Vidal-Valverde, C. Influence of fermentation conditions on glucosinolates, ascorbigen, and ascorbic acid content in white cabbage (Brassica oleracea var. capitata cv. Taler) cultivated in different seasons. J. Food Sci. 2009, 74, C62-C67. [CrossRef]

126. Palani, K.; Harbaum-Piayda, B.; Meske, D.; Keppler, J.K.; Bockelmann, W.; Heller, K.J.; Schwarz, K. Influence of fermentation on glucosinolates and glucobrassicin degradation products in sauerkraut. Food Chem. 2016, 190, 755-762. [CrossRef] [PubMed]

127. Tolonen, M.; Taipale, M.; Viander, B.; Pihlava, J.-M.; Korhonen, H.; Ryhanen, E.-L. Plant-derived biomolecules in fermented cabbage. J. Agric. Food Chem. 2002, 50, 6798-6803. [CrossRef]

128. Ciska, E.; Honke, J.; Drabinska, N. Changes in glucosinolates and their breakdown products during the fermentation of cabbage and prolonged storage of sauerkraut: Focus on sauerkraut juice. Food Chem. 2021, 365, 130498. [CrossRef] [PubMed]

129. Mullaney, J.A.; Kelly, W.J.; McGhie, T.K.; Ansell, J.; Heyes, J.A. Lactic acid bacteria convert glucosinolates to nitriles efficiently yet differently from Enterobacteriaceae. J. Agric. Food Chem. 2013, 61, 3039-3046. [CrossRef]

130. Luang-In, V.; Deeseenthum, S.; Udomwong, P.; Saengha, W.; Gregori, M. Formation of sulforaphane and iberin products from Thai cabbage fermented by myrosinase-positive bacteria. Molecules 2018, 23, 955. [CrossRef]

131. Ciska, E.; Pathak, D.R. Glucosinolate Derivatives in stored fermented cabbage. J. Agric. Food Chem. 2004, 52, 7938-7943. [CrossRef]

132. Penas, E.; Pihlava, J.M.; Vidal-Valverde, C.; Frias, J. Influence of fermentation conditions of Brassica oleracea L. var. capitata on the volatile glucosinolate hydrolysis compounds of sauerkrauts. LWT-Food Sci. Technol. 2012, 48, 16-23. [CrossRef]

133. Penas, E.; Limón, R.I.; Vidal-Valverde, C.; Frias, J. Effect of storage on the content of indole-glucosinolate breakdown products and vitamin C of sauerkrauts treated by high hydrostatic pressure. LWT-Food Sci. Technol. 2013, 53, 285-289. [CrossRef]

134. Cai, Y.X.; Augustin, M.A.; Jegasothy, H.; Wanga, J.H.; Terefe, N.S. Mild heat combined with lactic acid fermentation: A novel approach for enhancing sulforaphane yield in broccoli puree. Food Funct. 2020, 11, 779-786. [CrossRef] [PubMed]

135. Ye, J.-H.; Huang, L.-Y.; Terefe, N.S.; Augustin, M.A. Fermentation-based biotransformation of glucosinolates, phenolics and sugars in retorted broccoli puree by lactic acid bacteria. Food Chem. 2019, 286, 616-623. [CrossRef] [PubMed]

136. Xu, X.; Bi, S.; Lao, F.; Chen, F.; Liao, X.; Wu, J. Induced changes in bioactive compounds of broccoli juices after fermented by animal- and plant-derived Pediococcus pentosaceus. Food Chem. 2021, 357, 129767. [CrossRef]

137. Bhandari, S.R.; Kwak, J.H. Chemical composition and antioxidant activity in different tissues of Brassica vegetables. Molecules 2015, 20, 1228-1243. [CrossRef]

138. Frandsen, H.B.; Markedal, K.E.; Martin-Belloso, O.; Sanchez-Vega, R.; Soliva-Fortuny, R.; Sorensen, H.; Sorensen, S.; Sorensen, J.C. Effects of novel processing techniques on glucosinolates and membrane associated myrosinases in broccoli. Pol. J. Food Nutr. Sci. 2014, 64, 17-25. [CrossRef] 
139. Guo, R.F.; Yuan, G.F.; Wang, Q.M. Effect of $\mathrm{NaCl}$ treatments on glucosinolate metabolism in broccoli sprouts. J. Zhejiang Univ. Sci. $B$ 2013, 14, 124-131. [CrossRef] [PubMed]

140. Nugrahedi, P.Y.; Widianarko, B.; Dekker, M.; Verkerk, R.; Oliviero, T. Retention of glucosinolates during fermentation of Brassica juncea: A case study on production of sayur asin. Eur. Food Res. Technol. 2015, 240, 559-565. [CrossRef]

141. Walker, M.A.; Roberts, D.R.; Shih, C.Y.; Dumbroff, E.B. A requirement for polyamines during the cell division phase of radicle emergence in seeds of Acer saccharum. Plant Cell Physiol. 1985, 26, 967-972.

142. Baraldi, R.; Bertazza, G.; Bregoli, A.M.; Fasolo, F.; Rotondi, A.; Predieri, S.; Serafini-Fracassini, D.; Slovin, J.P.; Cohen, J.D. Auxins and polyamines in relation to differential in vitro root induction on microcuttings of two pear cultivars. J. Plant Growth Regul. 1995, 11, 21-31. [CrossRef]

143. Bais, H.P.; George, J.; Ravishankar, G.A. Influence of polyamines on growth of hairy root cultures of witloof chicory (Cichorium intybus L. cv. Lucknow local) and formation of coumarins. J. Plant Growth Regul. 1999, 18, 33-37. [CrossRef] [PubMed]

144. Bais, H.P.; Sudha, G.; Ravishankar, G.A. Putrescine influences growth and production of coumarins in hairy root cultures of Cichorium intybus L. cv. Lucknow local (witloof chicory). J. Plant Growth Regul. 1999, 18, 159-165. [CrossRef] [PubMed]

145. Bais, H.P.; Bhagyalakshmi, N.; Rajasekaran, T.; Ravishankar, G.A. Influence of polyamines on growth and production of secondary metabolites in hairy root cultures of Beta vulgaris and Tagetes patula. Acta Physiol. Plant. 2000, 22, 151-158. [CrossRef]

146. Jirage, D.B.; Ravishankar, G.A.; Suvarnalatha, G.; Venkataraman, L.V. Profile of polyamines during sprouting and growth of saffron (Crocus sativus L.) corms. J. Plant Growth Regul. 1994, 13, 69-72. [CrossRef]

147. Lee, T.M.; Lin, Y.H. Opposite effects of Fusicoccin and IAA on putrescine synthesis of rice coleoptiles. Physiol. Plant. 1996, 97, 63-68. [CrossRef]

148. Torrigiani, P.; Altamura, M.M.; Pasqua, G.; Monacelli, B.; Serafini-Fracassini, D.; Bagni, N. Free and conjugated polyamines during de novo floral and vegetative bud formation in thin cell layers of tobacco. Physiol. Plant. 1987, 70, 453-460. [CrossRef]

149. Gerats, A.G.M.; Kaye, C.; Collins, C.; Malmberg, R.L. Polyamine levels in Petunia genotypes with normal and abnormal floral morphologies. Plant Physiol. 1988, 86, 390-393. [CrossRef]

150. Bais, H.P.; Sudha, G.; Ravishankar, G.A. Putrescine and silver nitrate influences shoot multiplication, in vitro flowering and endogenous titres of polyamines in Cichorium intybus L. cv. Lucknow local. J. Plant Growth Regul. 2000, 19, 238-248. [CrossRef] [PubMed]

151. Teitel, D.C.; Cohen, E.; Arad, S.; Birnbaum, E.; Mizrahi, Y. The possible involvement of polyamines in the development of tomato fruits in vitro. Plant Growth Regul. 1985, 3, 309-317. [CrossRef]

152. Biasi, R.; Costa, G.; Bagni, N. Polyamine metabolism is related to fruit set and growth. Plant Physiol. Biochem. 1991, 29, 497-506.

153. Alabadi, D.; Aguero, M.S.; Perez-Amador, M.A.; Carbonell, J. Arginase, arginine decarboxylase, ornithine decarboxylase and polyamines in tomato ovaries: Changes in unpollinated ovaries and parthenocarpic fruits induced by auxin or gibberellin. Plant Physiol. 1996, 112, 1237-1244. [CrossRef]

154. Alabadi, D.; Carbonell, J. Expression of ornithine decarboxylase is transiently increased by pollination, 2,4-dichlorophenoxyacetic acid, and gibberellic acid in tomato ovaries. Plant Physiol. 1998, 118, 323-328. [CrossRef]

155. Kusano, T.; Yamaguchi, K.; Berberich, T.; Takahashi, Y. Advances in polyamine research in 2007. J. Plant Res. 2007, 120, 345-350. [CrossRef]

156. Kusano, T.; Yamaguchi, K.; Berberich, T.; Takahashi, Y. The polyamine spermine rescues Arabidopsis from salinity and drought stresses. Plant Signal. Behav. 2007, 2, 250-251. [CrossRef] [PubMed]

157. Capell, T.; Bassie, L.; Christou, P. Modulation of the polyamine biosynthetic pathway in transgenic rice confers tolerance to drought stress. Proc. Natl. Acad. Sci. USA 2004, 101, 9909-9914. [CrossRef]

158. Urano, K.; Yoshiba, Y.; Nanjo, T.; Ito, T.; Yamaguchi-Shinozaki, K.; Shinozaki, K. Arabidopsis stress-inducible gene for arginine decarboxylase AtADC2 is required for accumulation of putrescine in salt tolerance. Biochem. Biophys. Res. Commun. 2004, 313, 369-375. [CrossRef]

159. Kasukabe, Y.; He, L.; Nada, K.; Misawa, S.; Ihara, I.; Tachibana, S. Over-expression of spermidine synthase enhances tolerance to multiple environmental stresses and up-regulates the expression of various stress-regulated genes in transgenic Arabidopsis thaliana. Plant Cell Physiol. 2004, 45, 712-722. [CrossRef] [PubMed]

160. Kasukabe, Y.; He, L.; Watakabe, Y.; Otani, M.; Shimada, T.; Tachibana, S. Improvement of environmental stress tolerance of sweet potato by introduction of genes for spermidine synthase. Plant Biotechnol. 2006, 23, 75-83. [CrossRef]

161. Navakoudis, E.; Lutz, C.; Langebartels, C.; Lutz-Meindl, U.; Kotzabasis, K. Ozone impact on the photosynthetic apparatus and the protective role of polyamines. Biochim. Biophys. Acta 2003, 1621, 160-169. [CrossRef]

162. Wen, X.P.; Pang, X.M.; Matsuda, N.; Kita, M.; Inoue, H.; Hao, Y.-J.; Honda, C.; Moriguchi, T. Over-expression of the apple spermidine synthase gene in pear confers multiple abiotic stress tolerance by altering polyamine titers. Transgenic Res. 2007, 17, 251-263. [CrossRef]

163. Yamaguchi, K.; Takahashi, Y.; Berberich, T.; Imai, A.; Miyazaki, A.; Takahashi, T.; Michael, A.; Kusano, T. The polyamine spermine protects against high salt stress in Arabidopsis thaliana. FEBS Lett. 2006, 580, 783-788. [CrossRef] [PubMed]

164. Yamaguchi, K.; Takahashi, Y.; Berberich, T.; Imai, A.; Takahashi, T.; Michael, A.; Kusano, T. A protective role for the polyamine spermine against drought stress in Arabidopsis. Biochem. Biophys. Res. Commun. 2007, 352, 86-90. [CrossRef] [PubMed]

165. Takahashi, Y.; Berberich, T.; Miyazaki, A.; Seo, S.; Ohashi, Y.; Kusano, T. Spermine signalling in tobacco: Activation of mitogenactivated protein kinases by spermine is mediated through mitochondrial dysfunction. Plant J. 2003, 36, 820-829. [CrossRef] 
166. Cona, A.; Rea, G.; Angelini, R.; Federico, R.; Tavladoraki, P. Functions of amine oxidases in plant development and defence. Trends Plant Sci. 2006, 11, 80-88. [CrossRef]

167. Tun, N.N.; Santa-Catarina, C.; Begum, T.; Silveira, V.; Handro, W.; Floh, E.I.; Scherer, G.F. Polyamines induce rapid biosynthesis of nitric oxide (NO) in Arabidopsis thaliana seedlings. Plant Cell Physiol. 2006, 47, 346-354. [CrossRef]

168. Yamasaki, H.; Cohen, M.F. No signal at the crossroads: Polyamine-induced nitric oxide synthesis in plants? Trends Plant Sci. 2006, 11, 522-524. [CrossRef]

169. Jancewicz, A.L.; Gibbs, N.M.; Masson, P.H. Cadaverine's functional role in plant development and environmental response. Front. Plant Sci. 2016, 7, 870. [CrossRef] [PubMed]

170. Liu, Q.; Gao, T.; Liu, W.; Liu, Y.; Zhao, Y.; Liu, Y.; Li, W.; Ding, K.; Ma, F.; Li, C. Functions of dopamine in plants: A review. Plant Signal. Behav. 2020, 15, e1827782. [CrossRef]

171. Servillo, L.; Castaldo, D.; Giovane, A.; Casale, R.; D'Onofrio, N.; Cautela, D.; Balestrieri, M.L. Tyramine pathways in citrus plant defense: Glycoconjugates of tyramine and its N-methylated derivatives. J. Agric. Food Chem. 2017, 65, 892-899. [CrossRef]

172. Desgagne-Penix, I. Biosynthesis of alkaloids in Amaryllidaceae plants: A review. Phytochem. Rev. 2021, 20, 409-431. [CrossRef]

173. Nawaz, K.; Chaudhary, R.; Sarwar, A.; Ahmad, B.; Gul, A.; Hano, C.; Abbasi, B.H.; Anjum, S. Melatonin as master regulator in plant growth, development and stress alleviator for sustainable agricultural production: Current status and future perspectives. Sustainability 2021, 13, 294. [CrossRef]

174. Pastre, D.; Pietrement, O.; Landousy, F.; Hamon, L.; Sorel, I.; David, M.O.; Delain, E.; Zozime, A.; Le Cam, E. A new approach to DNA bending by polyamines and its implication in DNA condensation. Eur. Biophys. J. 2006, 35, 214-223. [CrossRef] [PubMed]

175. Lindemose, S.; Nielsen, P.E.; Mollegaard, N.E. Polyamines preferentially interact with bent adenine tracts in double-stranded DNA. Nucleic Acids Res. 2005, 33, 1790-1803. [CrossRef] [PubMed]

176. Ha, H.C.; Sirisoma, N.S.; Kuppusamy, P.; Zweier, J.L.; Woster, P.M.; Casero, R.A., Jr. The natural polyamine spermine functions directly as a free radical scavenger. Proc. Natl. Acad. Sci. USA 1998, 95, 11140-11145. [CrossRef]

177. Kim, I.G.; Oh, T.J. SOS induction of the recA gene by UV-, $\gamma$-irradiation and mitomycin $C$ is mediated by polyamines in Escherichia coli K-12. Toxicol. Lett. 2000, 116, 143-149. [CrossRef]

178. Tkachenko, A.; Nesterova, L.; Pshenichnov, M. The role of the natural polyamine putrescine in defence against oxidative stress in Escherichia coli. Arch. Microbiol. 2001, 176, 155-157. [CrossRef]

179. Chattopadhyay, M.K.; Tabor, C.W.; Tabor, H. Polyamines protect Escherichia coli cells from the toxic effect of oxygen. Proc. Natl. Acad. Sci. USA 2003, 100, 2261-2265. [CrossRef]

180. Karatan, E.; Duncan, T.R.; Watnick, P.I. NspS, a predicted polyamine sensor, mediates activation of Vibrio cholerae biofilm formation by norspermidine. J. Bacteriol. 2005, 187, 7434-7443. [CrossRef]

181. Patel, C.N.; Wortham, B.W.; Lines, J.L.; Fetherston, J.D.; Perry, R.D.; Oliveira, M.A. Polyamines are essential for the formation of plague biofilm. J. Bacteriol. 2006, 188, 2355-2363. [CrossRef]

182. Sturgill, G.; Rather, P.N. Evidence that putrescine acts as an extracellular signal required for swarming in Proteus mirabilis. Mol. Microbiol. 2004, 51, 437-446. [CrossRef]

183. Stevenson, L.G.; Rather, P.N. A novel gene involved in regulating the flagellar gene cascade in Proteus mirabilis. J. Bacteriol. 2006, 188, 7830-7839. [CrossRef] [PubMed]

184. Polissi, A.; Pontiggia, A.; Feger, G.; Altieri, M.; Mottl, H.; Ferrari, L.; Simon, D. Large-scale identification of virulence genes from Streptococcus pneumoniae. Infect. Immun. 1998, 66, 5620-5629. [CrossRef]

185. Ware, D.; Jiang, Y.; Lin, W.; Swiatlo, E. Involvement of potD in Streptococcus pneumoniae polyamine transport and pathogenesis. Infect. Immun. 2006, 74, 352-361. [CrossRef]

186. Molenaar, D.; Bosscher, J.S.; Ten Brink, B.; Driessen, A.J.M.; Konings, W.N. Generation of a proton motive force by histidine decarboxylation and electrogenic histidine/histamine antiport in Lactobacillus buchneri. J. Bacteriol. 1993, 175, 2864-2870. [CrossRef]

187. EFSA. Scientific opinion on risk-based control of biogenic amine formation in fermented foods. EFSA J. 2011, 9, 2393-2486. [CrossRef]

188. Soksawatmaekhin, W.; Kuraishi, A.; Sakata, K.; Kashiwagi, K.; Igarashi, K. Excretion and uptake of cadaverine by CadB and its physiological functions in Escherichia coli. Mol. Microbiol. 2004, 51, 1401-1412. [CrossRef] [PubMed]

189. Wolken, W.A.; Lucas, P.M.; Lonvaud-Funel, A.; Lolkema, J.S. The mechanism of the tyrosine transporter TyrP supports a proton motive tyrosine decarboxylation pathway in Lactobacillus brevis. J. Bacteriol. 2006, 188, 2198-2206. [CrossRef]

190. Sanchez-Perez, S.; Comas-Baste, O.; Rabell-Gonzalez, J.; Veciana-Nogues, M.T.; Latorre-Moratalla, M.L.; Vidal-Carou, M.C. Biogenic amines in plant-origin foods: Are they frequently underestimated in low-histamine diets? Foods 2018, 7, 205. [CrossRef]

191. Dala-Paula, B.M.; Starling, M.F.V.; Beatriz, M.; Gloria, A. Vegetables consumed in Brazilian cuisine as sources of bioactive amines. Food Biosci. 2021, 40, 100856. [CrossRef]

192. Cipolla, B.G.; Havouis, R.; Moulinoux, J.P. Polyamine contents in current foods: A basis for polyamine reduced diet and a study of its long-term observance and tolerance in prostate carcinoma patients. Amino Acids 2007, 33, 203-212. [CrossRef]

193. Nishibori, N.; Fujihara, S.; Akatuki, T. Amounts of polyamines in foods in Japan and intake by Japanese. Food Chem. 2007, 100, 491-497. [CrossRef]

194. Moret, S.; Smela, D.; Populin, T.; Conte, L.S. A survey on free biogenic amine content of fresh and preserved vegetables. Food Chem. 2005, 89, 355-361. [CrossRef] 
195. Simon-Sarkadi, L.; Holzapfel, W.H. Determination of biogenic amines in leafy vegetables by amino acid analyser. Z. Lebensm.Unters. Forsch. 1994, 198, 230-233. [CrossRef] [PubMed]

196. Bardocz, S.; Grant, G.; Brown, D.S.; Ralph, A.; Pusztai, A. Polyamines in food-Implications for growth and health. J. Nutr. Biochem. 1993, 4, 66-71. [CrossRef]

197. Eliassen, K.A.; Reistad, R.; Risøen, U.; Rønning, H.F. Dietary polyamines. Food Chem. 2002, 78, 273-280. [CrossRef]

198. Nishimura, K.; Shiina, R.; Kashiwagi, K.; Igarashi, K. Decrease in polyamines with aging and their ingestion from food and drink. J. Biochem. 2006, 139, 81-90. [CrossRef] [PubMed]

199. Garcia-Garcia, P.; Brenes-Balbuena, M.; Hornero-Mendez, D.; Garcia-Borrego, A.; Garrido-Fernandez, A. Content of biogenic amines in table olives. J. Food Prot. 2000, 63, 111-116. [CrossRef]

200. Swider, O.; Roszko, M.Ł.; Wójcicki, M.; Szymczyk, K. Biogenic Amines and Free Amino Acids in Traditional Fermented Vegetables-Dietary Risk Evaluation. J. Agric. Food Chem. 2020, 68, 856-868. [CrossRef]

201. Tsai, Y.-H.; Kung, H.-F.; Lin, Q.-L.; Hwang, J.-H.; Cheng, S.-H.; Wei, C.-I.; Hwang, D.-F. Occurrence of histamine and histamineforming bacteria in kimchi products in Taiwan. Food Chem. 2005, 90, 635-641. [CrossRef]

202. Cho, T.-Y.; Han, G.-H.; Bahn, K.-N.; Son, Y.-W.; Jang, M.-R.; Lee, C.-H.; Kim, S.-H.; Kim, D.-B.; Kim, S.-B. Evaluation of biogenic amines in Korean commercial fermented foods. Korean J. Food Sci. Technol. 2006, 38, 730-737.

203. Jin, Y.H.; Lee, J.H.; Park, Y.K.; Lee, J.-H.; Mah, J.-H. The occurrence of biogenic amines and determination of biogenic amineproducing lactic acid bacteria in Kkakdugi and Chonggak Kimchi. Foods 2019, 8, 73. [CrossRef]

204. Lee, J.-H.; Jin, Y.H.; Park, Y.K.; Yun, S.J.; Mah, J.-H. Formation of biogenic amines in Pa (green onion) Kimchi and Gat (mustard leaf) Kimchi. Foods 2019, 8, 109. [CrossRef] [PubMed]

205. Kang, K.H.; Kim, S.H.; Kim, S.-H.; Kim, J.G.; Sung, N.-J.; Lim, H.; Chung, M.J. Analysis and risk assessment of Nnitrosodimethylamine and its precursor concentrations in Korean commercial kimchi. J. Korean Soc. Food Sci. Nutr. 2017, 46, 244-250. [CrossRef]

206. Hornero-Mendez, D.; Garrido-Fernandez, A. Rapid High-Performance Liquid Chromatography analysis of biogenic amines in fermented vegetable brines. J. Food Prot. 1997, 60, 414-419. [CrossRef] [PubMed]

207. Garcia-Garcia, P.; Brenes-Balbuena, M.; Romero-Barranco, C.; Garrido-Fernandez, A. Biogenic amines in packed table olives and pickles. J. Food Prot. 2001, 64, 374-378. [CrossRef] [PubMed]

208. Shin, S.-W.; Kim, Y.-S.; Kim, Y.-H.; Kim, H.-T.; Eum, K.-S.; Hong, S.-R.; Kang, H.-J.; Park, K.-H.; Yoon, M.-H. Biogenic-amine contents of korean commercial salted fishes and cabbage kimchi. Korean J. Fish. Aquat. Sci. 2019, 52, 13-18.

209. Kalac, P.; Spicka, J.; Krizek, M.; Steidlova, S.; Pelikanova, T. Concentrations of seven biogenic amines in sauerkraut. Food Chem. 1999, 67, 275-280. [CrossRef]

210. Tofalo, R.; Schirone, M.; Perpetuini, G.; Angelozzi, G.; Suzzi, G.; Corsetti, A. Microbiological and chemical profiles of naturally fermented table olives and brines from different Italian cultivars. Antonie Van Leeuwenhoek 2012, 102, 121-131. [CrossRef] [PubMed]

211. Barbieri, F.; Montanari, C.; Gardini, F.; Tabanelli, G. Biogenic amine production by lactic acid bacteria: A review. Foods $2019,8,17$. [CrossRef] [PubMed]

212. Majcherczyk, J.; Surowka, K. Effects of onion or caraway on the formation of biogenic amines during sauerkraut fermentation and refrigerated storage. Food Chem. 2019, 298, 125083. [CrossRef] [PubMed]

213. Satora, P.; Skotniczny, M.; Strnad, S.; Piechowicz, W. Chemical composition and sensory quality of sauerkraut produced from different cabbage varieties. LWT-Food Sci. Technol. 2021, 136, 110325. [CrossRef]

214. Restuccia, D.; Loizzo, M.R.; Spizzirri, U.G. Accumulation of biogenic amines in wine: Role of alcoholic and malolactic fermentation. Fermentation 2018, 4, 6. [CrossRef]

215. Rabie, M.A.; Siliha, H.; el-Saidy, S.; el-Badawy, A.A.; Malcata, F.X. Reduced biogenic amine contents in sauerkraut via addition of selected lactic acid bacteria. Food Chem. 2011, 129, 1778-1782. [CrossRef]

216. Kalac, P.; Spicka, J.; Krizek, M.; Pelikanova, T. The effects of lactic acid bacteria inoculants on biogenic amines formation in sauerkraut. Food Chem. 2000, 70, 355-359. [CrossRef]

217. Kalac, P.; Spicka, J.; Krizek, M.; Pelikanova, T. Changes in biogenic amine concentrations during sauerkraut storage. Food Chem. 2000, 69, 309-314. [CrossRef]

218. Kosson, R.; Elkner, K. Effect of storage period on biogenic amine content in sauerkraut. Veg. Crop. Res. Bull. 2010, 73, 151-160. [CrossRef]

219. Penas, E.; Frias, J.; Sidro, B.; Vidal-Valverde, C. Impact of fermentation conditions and refrigerated storage on microbial quality and biogenic amine content of sauerkraut. Food Chem. 2010, 123, 143-150. [CrossRef]

220. Spicka, J.; Kalac, P.; Bover-Cid, S.; Krízek, M. Application of lactic acid bacteria starter cultures for decreasing the biogenic amine levels in sauerkraut. Eur. Food Res. Technol. 2002, 215, 509-514.

221. Mah, J.-H.; Kim, Y.J.; No, H.-K.; Hwang, H.-J. Determination of biogenic amines in kimchi, Korean traditional fermented vegetable products. Food Sci. Biotechnol. 2004, 13, 826-829.

222. Kang, H.-W. Characteristics of kimchi added with anchovy sauce from heat and non-heat treatments. Culin. Sci. Hosp. Res. 2013, $19,49-58$. 
223. Alan, Y. Culture fermentation of Lactobacillus in traditional pickled gherkins: Microbial development, chemical, biogenic amine and metabolite analysis. J. Food Sci. Technol. 2019, 56, 3930-3939. [CrossRef] [PubMed]

224. Garcia-Garcia, P.; Romero Barranco, C.; Duran Quintana, M.C.; Garrido Fernandez, A. Biogenic amine formation and "zapatera" spoilage of fermented green olives: Effect of storage temperature and debittering process. J. Food Prot. 2004, 67, 117-123. [CrossRef] [PubMed] 